Invited review

\title{
Viral surface glycoproteins, gp120 and gp41, as potential drug targets against HIV-1: Brief overview one quarter of a century past the approval of zidovudine, the first anti-retroviral drug
}

\author{
Cátia Teixeira $^{\mathrm{a}, \mathrm{b}, \mathrm{c}}$, José R.B. Gomes ${ }^{\mathrm{b}}$, Paula Gomes ${ }^{\mathrm{c}, *}$, François Maurel ${ }^{\mathrm{a}}$ \\ a ITODYS, Université Paris Diderot, CNRS - UMR7086, 15 Rue Jean Antoine de Baif, 75205 Paris Cedex 13, France \\ ${ }^{\mathrm{b}}$ CICECO, Universidade de Aveiro, Campus Universitário de Santiago, P-3810-193 Aveiro, Portugal \\ ${ }^{c}$ Centro de Investigação em Química da Universidade do Porto, Departamento de Química e Bioquímica, Faculdade de Ciências, Universidade do Porto, R. Campo Alegre, 687, \\ P-4169-007 Porto, Portugal
}

\section{A R T I C L E I N F O}

\section{Article history:}

Received 22 September 2010

Received in revised form

15 January 2011

Accepted 25 January 2011

Available online 3 February 2011

\section{Keywords:}

gp120

gp41

HIV-1

HIV-1 entry inhibitors

Molecular modeling

\begin{abstract}
A B S T R A C $T$
The first anti-HIV drug, zidovudine (AZT), was approved by the FDA a quarter of a century ago, in 1985 . Currently, anti-HIV drug-combination therapies only target HIV-1 protease and reverse transcriptase. Unfortunately, most of these molecules present numerous shortcomings such as viral resistances and adverse effects. In addition, these drugs are involved in later stages of infection. Thus, it is necessary to develop new drugs that are able to block the first steps of viral life cycle. Entry of HIV-1 is mediated by its two envelope glycoproteins: gp120 and gp41. Upon gp120 binding to cellular receptors, gp41 undergoes a series of conformational changes from a non-fusogenic to a fusogenic conformation. The fusogenic core of gp41 is a trimer-of-hairpins structure in which three C-terminal helices pack against a central trimericcoiled coil formed by three N-terminal helices. The formation of this fusogenic structure brings the viral and cellular membranes close together, a necessary condition for membrane fusion to occur. As gp120 and gp41 are attractive targets, the development of entry inhibitors represents an important avenue of anti-HIV drug therapy. The present review will focus on some general considerations about HIV, the main characteristics of gp120, gp41 and their inhibitors, with special emphasis on the advances of computational approaches employed in the development of bioactive compounds against HIV- 1 entry process.

(C) 2011 Elsevier Masson SAS. All rights reserved.
\end{abstract}

\section{Introduction}

On June 5,1981, Morbidity and Mortality Weekly Report (MMWR) published a report of five cases of Pneumocystis carinii pneumonia (PCP) among previously healthy young men in Los Angeles. Local clinicians prepared the report and submitted it for MMWR publication in early May 1981. Before publication, MMWR editorial staff sent the submission to Centre for Disease Control (CDC) experts in parasitic and sexually transmitted diseases. The editorial note that accompanied the published report stated that the case histories suggested a "cellularimmune dysfunction related to a common exposure" and a "disease acquired through sexual contact." The report prompted additional case reports from New York City, San Francisco, and other cities. In June 1981, CDC developed an

\footnotetext{
* Corresponding author. Tel.:+351 220402563; fax: +351 220402659

E-mail address: pgomes@fc.up.pt (P. Gomes).
}

investigative team to identify risk factors and to develop a case definition for national surveillance. Within 18 months, epidemiologists conducted studies and prepared MMWR reports that identified all of the major risks factors for acquired immunodeficiency syndrome (AIDS). In March 1983, CDC issued recommendations for prevention of sexual, drug-related, and occupational transmission based on these early epidemiologic studies and before the cause of the new, unexplained illness was known.

in Morbidity and Mortality Weekly Reports [1].

As researchers began to describe the epidemiology and risk factors in a systematic way, many theories emerged as the cause of the mysterious disease. An infective agent was postulated and, in 1983, a novel human retrovirus was isolated as the putative etiological agent [2-4]. That virus was eventually named Human Immunodeficiency Virus, or HIV [5].

What started as five identified cases in Los Angeles has grown to an estimated 33.4 million cases worldwide in 2008, according to the Joint United Nations Programme on HIV/AIDS [6]. Globally, 
nowadays, AIDS remains one of the major threatening diseases known to mankind and current treatment regimens are undetermined by poor long-term effects and high costs. The effectiveness of available treatment is mainly reduced due to severe side effects and the emergence of drug-resistant HIV strains, which urge for the development of new and improved drugs.

The intense study of the life cycle of HIV has created new and potential targets for drug discovery efforts. Among these, glycoprotein 120 (gp120) and glycoprotein 41 (gp41), involved in different stages of viral entry into cells, have emerged as promising targets against HIV. In this article, we will briefly review some general considerations about HIV, the main characteristics of gp120, gp41 and their inhibitors with a special focus on some advances of computational approaches employed in the development of bioactive compounds against HIV-1 entry process.

\subsection{Types, groups and sub-types of HIV}

The virus is a member of the Retrovirus family and the Lentivirus genus. As a retrovirus, HIV contains a single-stranded RNA genome that is converted to DNA by the viral enzyme reverse transcriptase and inserted into the host genome. As a lentivirus, HIV is able to infect nondividing cells and causes prolonged, but ultimately fatal, disease [7].

Two distinct types of HIV have been identified: HIV-1 and HIV-2. They are differentiated by their geographical origin and the organization of their genome. Worldwide, the predominant virus is HIV-1, and generally when people refer to HIV without specifying the type of virus they will be referring to HIV-1. The relatively uncommon HIV-2 type is concentrated in West Africa and is rarely found elsewhere [8].

Phylogenetic analyses of numerous strains of HIV-1, isolated from diverse geographic origins, have revealed that the virus can be subdivided into groups, sub-types, sub-subtypes and circulating recombinant forms [9-11]. HIV-1 has been further divided into three virus groups: the predominant $\mathrm{M}$ group, which is responsible for most of the epidemic, $\mathrm{N}$ and $\mathrm{O}$ [9]. Group $\mathrm{M}$ is divided into eleven sub-types (clades) ( $\mathrm{A}-\mathrm{K})$. The sub-type $\mathrm{B}$ infects the majority of people with AIDS in America, Europe, Asia and Australia, whereas clades A, C, D and E are found widely in Africa. However, various other group $M$ sub-types have been reported in the US and several European countries [12-18].

The origin of HIV-1 is thought to be a cross-species transmission (zoonosis) of a Simian Immunodeficiency Virus (SIV) from a subspecies of Chimpanzee (Pan troglodytes troglodytes) [19] but probably from different events for each group [20-22]. The date of the zoonosis events have not been precisely discovered but antibodies against group-M HIV-1 were found in a serum sample collected in the Belgian Congo in 1959 [23]. Models of the genetic divergence of the 11 sub-types of group $\mathrm{M}$ date a common ancestor somewhere around 1915-1941 [24].

\subsection{Targets cells of HIV-1}

HIV primarily infects varieties of immune cells such as macrophages (hence M-tropic), microglial cells (type of brain glial cell that acts as the immune cells), and lymphocyte T-cells, namely CD4 T-cells, which make up a quarter of the white blood cell count and were found to be the main target of HIV-1 infection [25]. We know that HIV-1 infects preferably the cells that express CD4 and one of the co-receptors (CCR5 or CXCR4). However, some studies show that HIV-1 would also have the ability to infect cells lacking CD4, including B lymphocytes [26], astrocytes [27,28], thymocytes [29], CD8+ T lymphocytes [30], denditric cells [31] and epithelial cells, namely trophoblasts [32].
Cell infection by HIV-1 can be divided into three phases. During the first phase, infection progresses fairly rapidly and may exhibit mononucleosis-like symptoms within a few weeks [33]. During this early phase, the extent of infection is high and virion (virus particle) concentration may exceed a million copies per $\mathrm{mL}$ of blood [34]. The host's immune response usually kicks in after a few weeks and the level of virus in the blood declines to bring HIV-1 infection into its second phase. Viral replication is still active and cells are rapidly being infected and eliminated during this period [35,36]. The turnover of T-cells gradually leads to a decline in their number [37]. In the third and final phase of infection, the number of CD4 T-cells drops more quickly and the viral load increases to produce clinical immunodeficiency.

\subsection{Transmission}

The efficiency of the transmission of HIV-1, from one individual to another, depends mainly on two conditions: the presence of sufficient virus in a body fluid and a gateway to this one. The blood, semen, vaginal secretions and breast milk are the fluids that contain the higher virus load $[38,39]$. Transmissions through sexual contact or through blood (drug addiction, accidents, blood transfusions) are the common ways to transmit the virus. But, the transmission is also possible from mother to child during pregnancy, at childbirth or during breastfeeding. A high viral load ( $>1500$ virus/mL) [40], careless sexual behavior [41-44] and some periods of the menstrual cycle $[45,46]$ are all factors that may increase the chances of transmission.

\subsection{Virus structure and genomic organization}

Approximately $120 \mathrm{~nm}$ in diameter, the HIV-1 virion (Fig. 1) contains at this center two single-stranded RNA molecules coated with viral nucleocapsid (NC) protein, or p24. This core and the trio of viral enzymes, protease (PR), reverse transcriptase (RT), and integrase (IN), are enclosed within a cage of structural capsid (CA) and matrix (MA) protein, or p17. The outermost shell of the virus

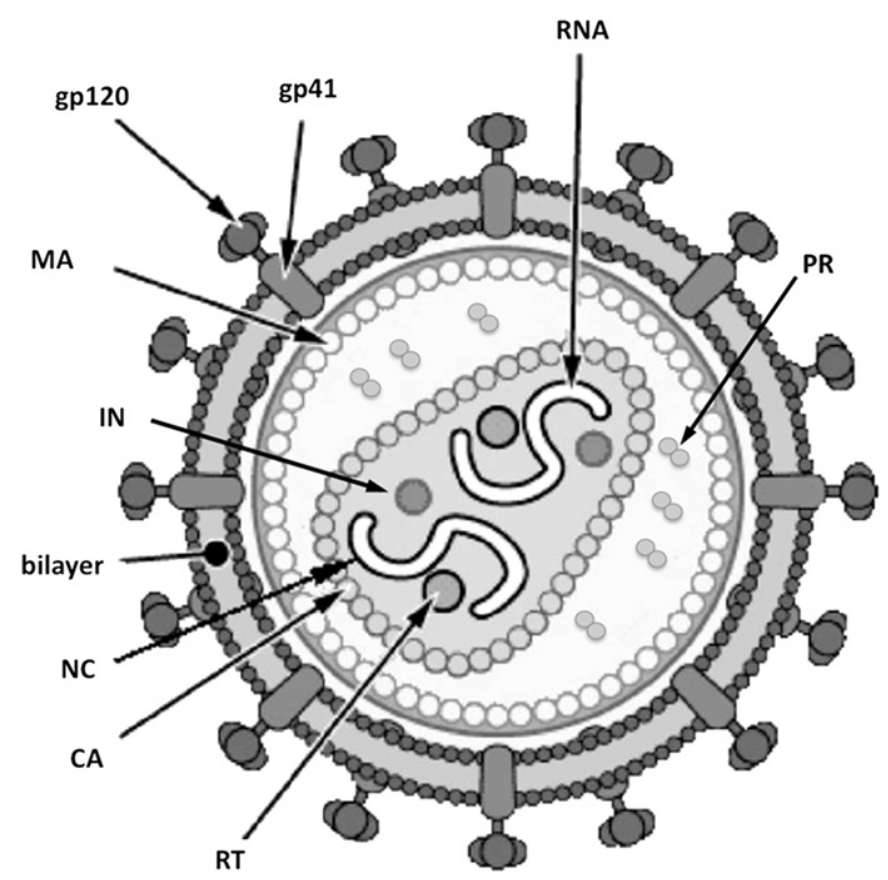

Fig. 1. Diagram of HIV-1 mature virion. MA: matrix protein; NC: nucleocapsid protein; CA: structural capsid protein; RT: reverse transcriptase; IN: integrase; PR: protease. 
consists of the envelope protein, gp120 and gp41, embedded in a lipid bilayer.

The HIV-1 genome (Fig. 2) encodes three major polyproteins that are common to all retroviruses: Gag, Pol and Env. Gag, a polyprotein that is cleaved into MA, CA and NC proteins, and Env, cleaved into gp160 that in turn originates gp120 and gp41, are structural genes. The Pol precursor protein encodes the viral enzymes protease (PR), reverse transcriptase (RT), and integrase (IN). The virus also contains regulatory proteins, Tat and Rev, as well as the accessory proteins Vif, Vpr, Vpu and Nef. The accessory proteins were initially thought to be dispensable for viral replication, but this view is changing following more recent in vivo experiments. Vif may either increase viral infectivity or may allow productive infections of otherwise non-permissive cell types [47]. Vpr functions early in the viral life cycle, most likely in transport of the viral genome to the nucleus [48]. Vpu enhances virus budding and degrades cellular CD4 [49]. Nef also has similar functions, and appears to be required for disease induction in vivo [50].

\subsection{HIV-1 life cycle}

Understanding the interplay of HIV-1 with its cellular host provides the biological basis for attempting to control the epidemic. A schematic representation of the replication cycle of HIV appears in Fig. 3. With over 300000 articles indexed for HIV or AIDS on Medline [51] it is certainly one of the most thoroughly studied systems today. This way, many details of the biology of HIV will be omitted for the sake of brevity.

\subsubsection{Virus entry}

The entry of HIV into a host cell may be divided into 3 distinct steps: attachment, co-receptor interaction and fusion. Attachment of HIV-1 to the host cell surface is mediated through the glycoprotein (gp120) on the virion surface binding to a CD4 receptor on the host cell. This gp120-CD4 complex interacts with a co-receptor on the cell surface, typically chemokine CXCR4 or CCR5. Transmembrane glycoprotein gp41 mediates membrane fusion to complete virus entry into the host cell.

\subsubsection{Uncoating the capsid core}

Following fusion, the capsid core is disrupted to dump the contents into the cytoplasm of the host cell.

\subsubsection{Reverse transcription}

Successful entry of the contents of the viral core is followed by the reverse transcription of the viral RNA template into its complementary DNA strand. This is performed by an enzyme of the virus, RT, in a complex with other viral proteins. RT then degrades the RNA template to subsequently produce the double-stranded viral DNA. RT is highly error-prone since it is unable to catalyze the proof-reading usually performed by a normal DNA polymerase.

\subsubsection{Nuclear import and integration}

The newly synthesized viral DNA is then imported into the nucleus of the host cell. The properly placed viral DNA is processed and transferred to the host genome by the viral enzyme integrase. Once the viral DNA has been inserted, infection in that cell is for all intents and purposes permanent. At this stage, the virus is known as a provirus. Thereafter, HIV may persist in a latent, proviral state for many years in unstimulated cells.

\subsubsection{Transcription and translation}

Activation of the host cells and, consequently, the synthesis of the viral genome, begin with the transcription, by RNA polymerase, of the proviral DNA into RNA. Then the RNA is transported outside the nucleus for translation by the ribosome. The viral RNA contains the code to produce the capsid proteins and other proteins needed for viral assembly. In spliced form, the RNA also codes for the envelope proteins and other auxiliary proteins. Envelope proteins are produced in the rough endoplasmic reticulum, and then move through the Golgi apparatus before arriving the cell surface.

\subsubsection{Assembly, budding and proteolytic maturation}

Assembly of a new virus particle begins at the cell surface with the clustering of the newly produced viral proteins together with two copies of the viral genomic RNA. As the virion assembles at the plasma membrane, it induces curvature that allows it to bud off that membrane. This particle is initially non-infectious and is known as an immature virion. The budding process leads to the explosion of the human cell. This immature virion then suffers reorganization to its mature form. HIV protease (PR) is required at this stage to cleave the Gag and Gag-Pol polyproteins into their four structural proteins and the PR, RT and IN functional enzymes.

\subsection{Current targets of anti-HIV-1 chemotherapy}

Twenty-five years after the discovery of AZT, relevant topics and perspectives on past, present and future of anti-retroviral therapy were reviewed by other authors [53-55] on a special issue of Antiviral Research devoted to this subject. During the last three decades, we have witnessed an impressive scientific effort to understand the mechanism underlying the immunosuppressive and clinically devastating effects of HIV-1 infection. This has led to the discovery of viral and human genes involved in the regulation of a variety of viral and host functions. Consequently, research has also rapidly utilized this knowledge to design drugs that block viral replication [56-59].

Considering the steps of the HIV-1 life cycle, theoretically, all of them represent targets for anti-retroviral therapy. However, to date the three major groups of drugs being used in the clinical practice are the reverse transcriptase inhibitors (nucleoside/nucleotide, NRTI, and non-nucleoside, NNRTI) and the protease inhibitors (PI). In recent years, three additional drugs have been approved, each representing a new class of anti-retroviral inhibitors by targeting different steps of the HIV-1 life cycle: enfuvirtide, which binds to gp41 thus blocking the fusion process [60], raltegravir, targeting the viral integrase enzyme [61] and maraviroc, targeting the cellular HIV-1 entry co-factor CCR5 [62], see Table 1.

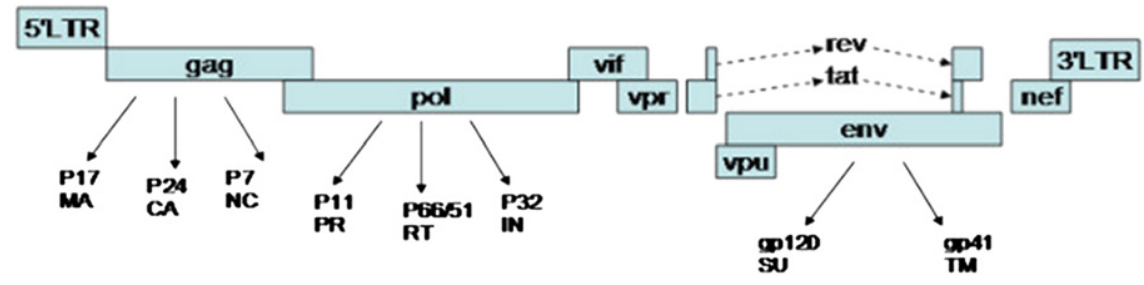

Fig. 2. Structure of the HIV-1 genome. 


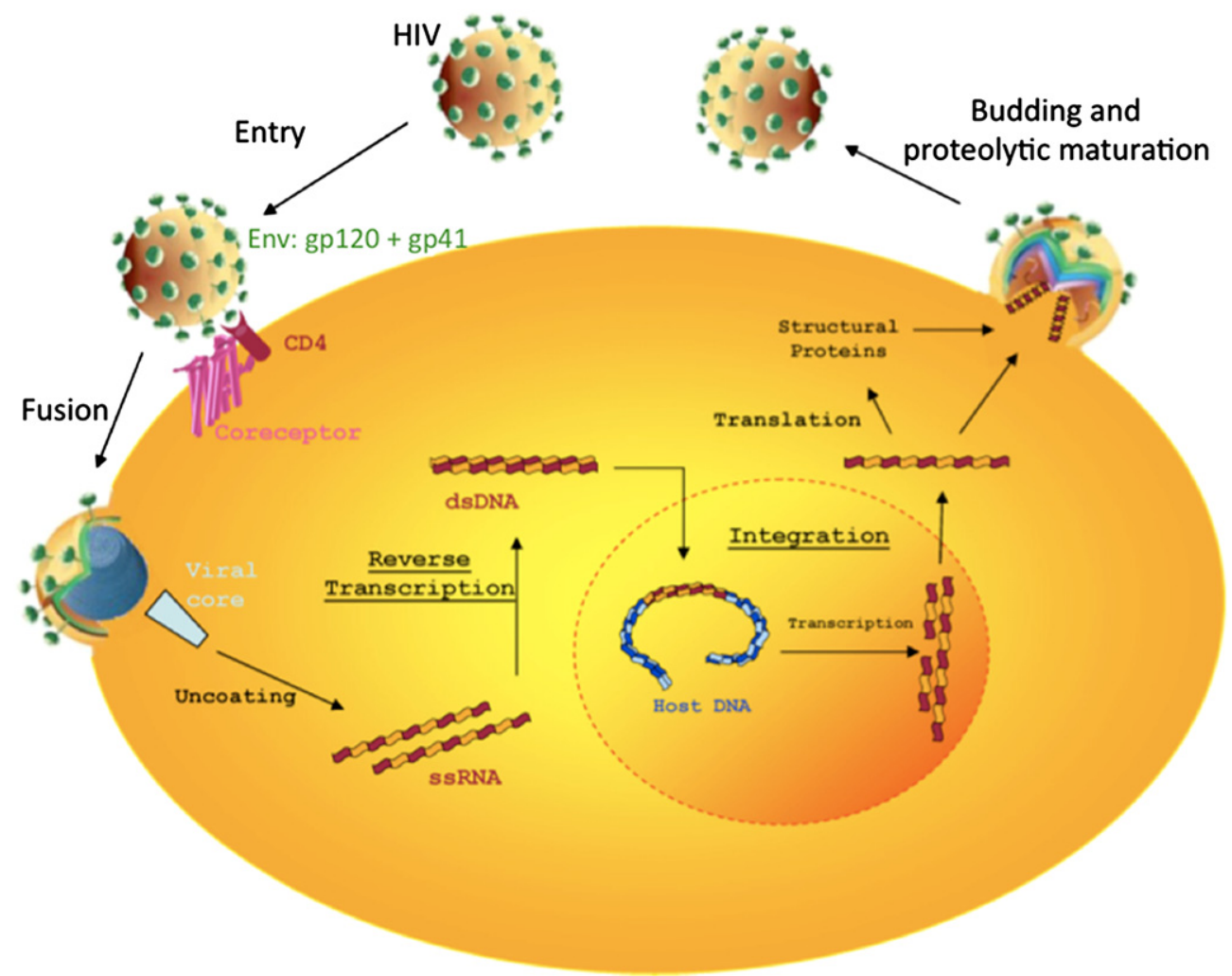

Fig. 3. The life cycle of HIV-1. Adapted from Ref. [52].

The current therapeutic strategy, the so-called highly active anti-retroviral therapy (HAART), involves the use of agents from at least two distinct classes of antiretrovirals [63]. The introduction of HAART has dramatically improved the survival of patients infected with HIV-1. However HAART is complicated by the continuing emergence of drug-resistant strains of HIV and toxicities associated with the anti-retroviral agents [64,65]. Furthermore, since the combination HAART regimens are unable to eradicate HIV infection, lifelong therapy is required to avoid disease progression $[66,67]$. Together, these factors necessitate the continual development of new inhibitors that can be used against resistant viruses. HAART regimens have been predominantly focused on two viral enzymes, RT and PR. New anti-retroviral agents under development include integrase inhibitors as well as compounds that target components of the viral entry pathway. These later compounds are known as entry/fusion inhibitors and are the subject of this review. In fact, these molecules show remarkable efficacy against viruses that are resistant to the other three classes of inhibitors (NRTI, NNRTI and PI). In addition, acting outside the cellular environment represents a great advantage of this novel class of anti-retroviral drugs.

\section{HIV-1 entry}

HIV-1 entry is not a simple task. The Env polyprotein of HIV-1 is the molecular determinant for viral attachment and membrane fusion. Env is synthesized as a single polypeptide precursor (gp160) that forms non covalently associated homotrimers, and which is cleaved during transport to the cell surface into two subunits, gp120 and gp41 (Fig. 4a). As we have seen before, entry of HIV-1 into cells involves three distinct stages: binding of gp120 to CD4, binding of gp120 to a co-receptor, and gp41-mediated fusion of the viral and host membranes (see Fig. 4b).
All these three steps have been considered for the drug design of HIV-1 entry inhibitors [69]. However, it is preferable to develop anti-HIV drugs targeting viral proteins (gp120 and gp41) rather than host cell molecules (CD4, CCR5 and CXCR4), because it is a concern that binding the cellular molecules might interfere with their normal functions, causing toxic or adverse effects. Despite this general truth, CCR5 has been intensively studied and validated as a target for HIV therapy [70,71] since the discovery that the homozygous Delta 32 deletion in CCR5 confers resistance to HIV-1 in normal survey people [72-74]. For a review about chemokine

Table 1

Approved anti-retroviral drugs for the treatment of HIV-1 infection [52].

\begin{tabular}{|c|c|c|}
\hline Target & Drug class & Substance (abbreviation, commercial name ${ }^{\circledR}$ ) \\
\hline CCR5 & $\begin{array}{l}\text { Entry } \\
\text { inhibitors }\end{array}$ & Maraviroc (UK-427 857, Selzentry ${ }^{\circledR}$ ) \\
\hline $\begin{array}{l}\text { gp41 } \\
(\mathrm{N}- \\
\mathrm{HR})\end{array}$ & $\begin{array}{l}\text { Fusion } \\
\text { inhibitors }\end{array}$ & Enfuvirtide (T20, Fuzeon ${ }^{\circledR}$ ) \\
\hline IN & $\begin{array}{l}\text { Integrase } \\
\text { inhibitors }\end{array}$ & Raltegravir (MK-0518, Isentress ${ }^{\circledR}$ ) \\
\hline RT & NRTI & $\begin{array}{l}\text { Abacavir }\left(\text { ABC, Ziagen }{ }^{\circledR}\right) \text {, Didanonise }\left(\text { ddI, Videx }^{\circledR}\right) \text {, } \\
\text { Emtricitabine }\left(\text { FTC, Emtriva }{ }^{\circledR}\right) \text {, Stavudine }\left(\mathrm{d} 4 \mathrm{~T}, \text { Zerit }^{\circledR}\right) \text {, } \\
\left.\left.\text { Lamivudine (3TC, Epivir }{ }^{\circledR}\right) \text {, Tenofovir (DF, Viread }{ }^{\circledR}\right) \text {, } \\
\text { Zalcitabine }\left(\text { ddC, Hivid }^{\circledR}\right) \text {, Zidovudine (AZT, Retrovir }{ }^{\circledR} \text { ) }\end{array}$ \\
\hline RT & NNRTI & $\begin{array}{l}\left.\text { Delavirdine (DLV, Rescriptor }{ }^{\circledR}\right) \text {, Efavirenz (EFV, } \\
\left.\text { Sustiva }^{\circledR}\right) \text {, Etravirine }\left(\text { TMC125, Intelence }^{\circledR}\right) \text {, Nevirapine } \\
\left.\text { (NVP, Viramune }^{\circledR}\right)\end{array}$ \\
\hline PR & PI & $\begin{array}{l}\text { Amprenavir (AMP, Agenerase }{ }^{\circledR} \text { ), Atazanavir (ATZ, } \\
\text { Reyataz }^{\circledR} \text { ), Darunavir }\left(\text { TMC114, Prezista }^{\circledR} \text { ), }\right. \\
\left.\text { Fosamprenavir (GW-433908, Lexiva }{ }^{\circledR}\right) \text {, Indinavir (IDV, } \\
\text { Crixivan }^{\circledR} \text { ), Lopinavir combined with Ritonavir (ABT- } \\
\text { 378, Kaletra }{ }^{\circledR} \text { ), Nelfinavir (NFV, Viracept }{ }^{\circledR} \text { ), Ritonavir } \\
\text { (RTV, Norvir }^{\circledR} \text { ), Saquinavir (SQV, Fortovase }{ }^{\circledR} \text {, Invirase }{ }^{\circledR} \text { ), } \\
\text { Tipranavir (TPV, Aptivus }{ }^{\circledR} \text { ) }\end{array}$ \\
\hline
\end{tabular}




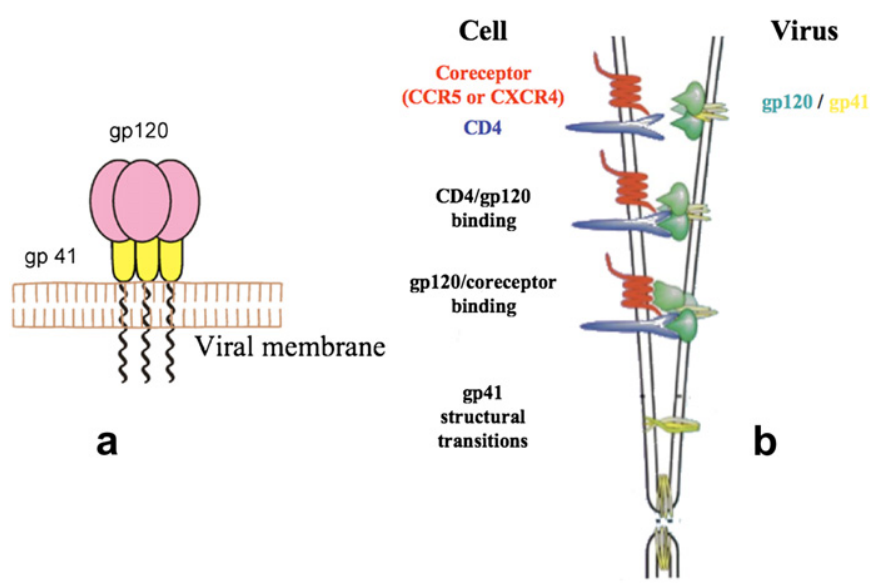

Fig. 4. a) Representation of the structure of gp120 and gp41 at the surface of the viral membrane. b) Schematic form of the HIV entry pathway; CD4 is shown in blue, coreceptor (either CCR5 or CXCR4) in red, gp120 in green, gp41 in yellow. The sequence of events in the entry pathway is depicted in temporal order from top (before virus entry) to bottom (fusion of viral and cellular membrane). Adapted from Ref. [68]. (For interpretation of the references to color in this figure legend, the reader is referred to the web version of this article.)

receptor antagonists please see Ref. [75]. In the subsequent sections, we will just refer to the therapeutic compounds that target viral envelope proteins. We will see in more detail the structure and mechanisms of action/inhibition of these two proteins, gp120 and gp41, that permit HIV-1 to gain access to the inside of human cells.

\subsection{Structure of HIV-1 gp120}

HIV-1 gp120 consists of five conserved (C1-C5) and five variable (V1-V5) protein domains [76]. The conserved domains contribute to the core of gp120, while the variable domains (and numerous $\mathrm{N}$-linked glycosylation sites) are located near the surface of the molecule. The V1-V5 regions form exposed "loops" anchored at their bases by disulfide bonds [77].

The gp120 molecule has proven to be difficult to crystallize in its entirety, but several structures have been solved in recent years, including a deglycosylated HIV-1 gp120 bound to CD4 and lacking the V1-V3 loops as well as containing truncations at the $\mathrm{N}$ and $\mathrm{C}$ termini [79]. From this structure (Fig. 5), it is evident that in its native state, gp120 contains two distinct regions: an inner domain that is involved in interactions with gp41 and the formation of trimeric envelope spikes, and an outer domain that forms a large part of the exposed surface of the spikes and is heavily glycosylated. Binding of CD4 to gp120 induces significant conformational changes that result in the formation of a third domain termed the bridging sheet. This domain consists of two pairs of anti-parallel $\beta$ sheets that link the inner and outer domains, and plays a major role in interacting with the viral co-receptors [80].

\subsection{Mechanism of action of gp120}

The primary receptor for HIV-1 is CD4, a member of the immunoglobulin superfamily. CD4 makes contact with the gp120 molecule (Fig. 6) at a depression near the intersection of the inner domain, outer domain and bridging sheet.

CD4 binding appears to induce the formation of the bridging sheet domain itself, as the two pairs of $\beta$-sheets are spatially separated in a crystal structure of the unbound core of SIV gp120 but come together to form a four-stranded sheet in the CD4-bound conformation $[79,81,82]$. Additional changes in gp120 occur with

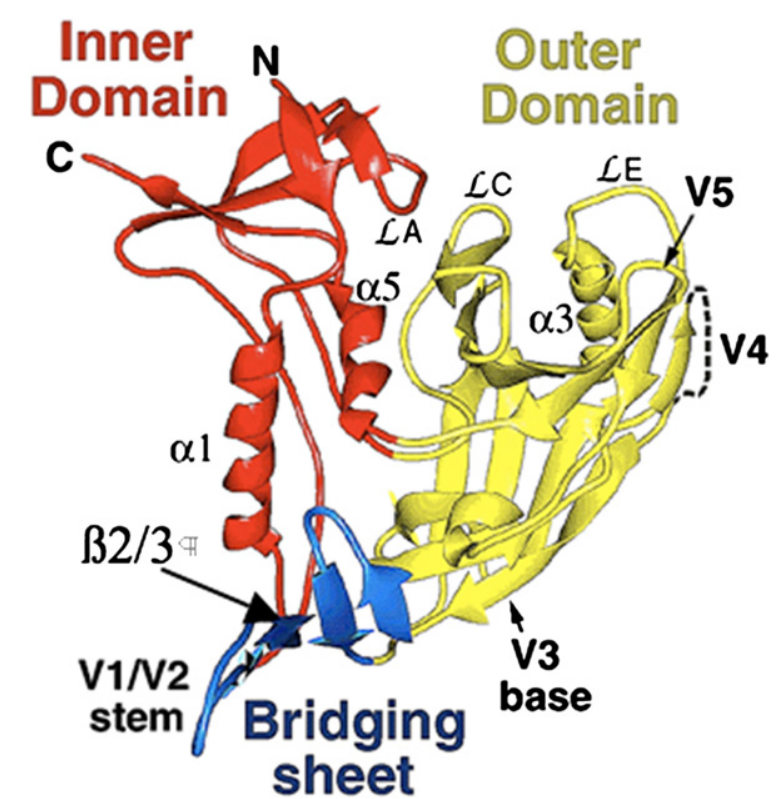

Fig. 5. Core gp120 showing the inner domain, outer domain, and bridging sheet. Adapted from Ref. [78].

CD4 binding, including movement of the V1/V2 and V3 loop domains. As a result, CD4 binding not only induces the formation of the bridging sheet, as it likely also enhances exposure of this region and orients it and the V3 loop toward the target cell membrane, where they can engage the viral co-receptor $[83,84]$.

The HIV-1 gp120 envelope protein is an essential component in the multi-tiered viral entry process. Despite the overall genetic heterogeneity of the gp120 glycoprotein, the highly conserved CD4 binding site provides an attractive antiviral target. Indeed, the receptor binds within a recessed pocket in the gp120 core. Main chain atoms of gp120 play prominent roles, contributing more than half of the contacts with CD4. Particularly intriguing are two large interior cavities at the gp120-CD4 interface, created by topographical mismatches between the surfaces of the two proteins. The smaller cavity extends deeply (10 ̊) into the hydrophobic interior of gp120; it is plugged by the phenyl ring of CD4 Phe43,

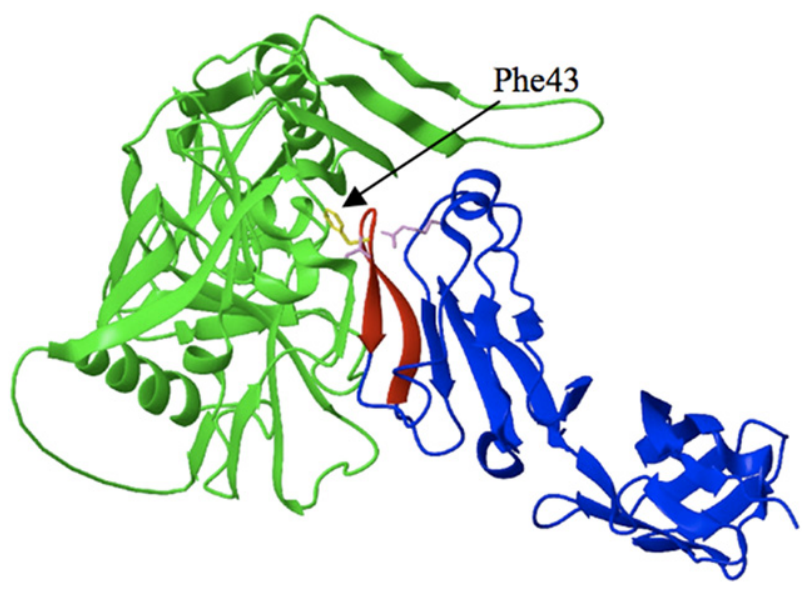

Fig. 6. Structure of gp120 (green) bound to CD4 receptor (in blue). In red is represented the zone of CD4 that interacts with gp120 and in yellow the residue of CD4, Phe43, which plays an important role in such interaction. (For interpretation of the references to color in this figure legend, the reader is referred to the web version of this article.) 


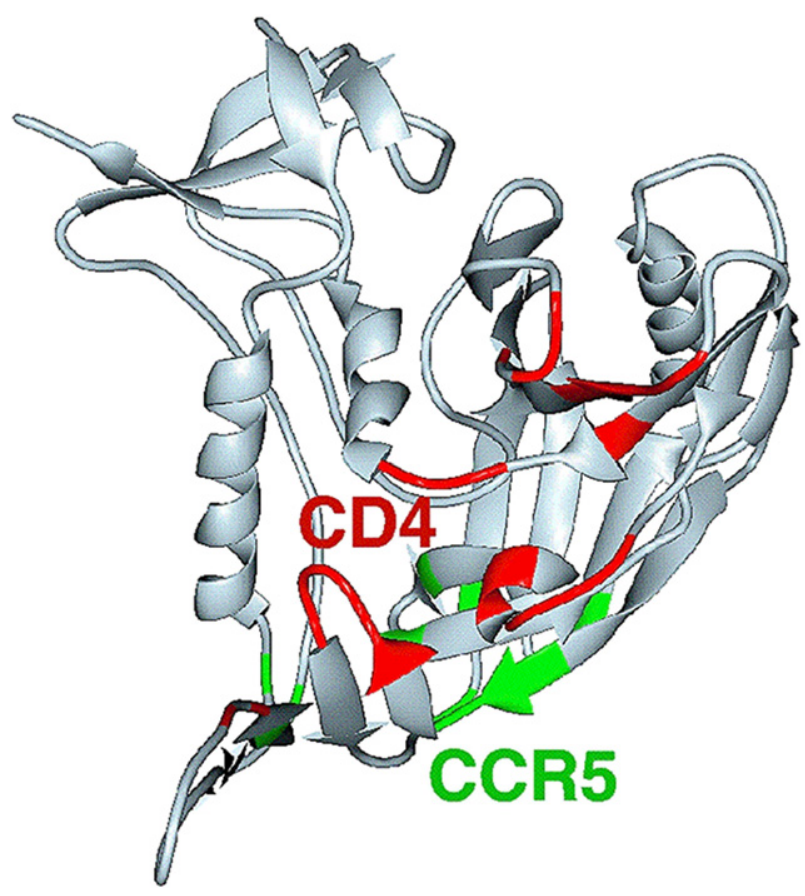

Fig. 7. Structure of gp120 core: residues within $4 \AA$ of $\mathrm{CD} 4$ (red) and important binding residues (green). From Ref. [78]. (For interpretation of the references to colour in this figure legend, the reader is referred to the web version of this article.)

a residue previously implicated in gp120 binding based on CD4 mutagenesis studies [85]. This residue is quite significant in CD4-gp120 binding because it is estimated that it alone accounts for $23 \%$ of the total energy of CD4-gp120 binding [86].

Also puzzling is the highly conserved nature of the hydrophobic gp120 residues that line this cavity; the side chains make minimal contacts with CD4, and substitutions would not appear to cause steric hindrance. The functional significance of the conservation of these residues remains unclear. The larger cavity is less buried on the surface of the gp120 core; it is water filled and lined with hydrophilic residues from both gp120 and CD4. Highly conserved gp120 residues (Asp368, Glu370, and Trp427 at one end, Asp457 at the other) flank this cavity, which make direct contacts with CD4 (Fig. 7).

\subsection{Structure of HIV-1 gp41}

The HIV-1 gp41 envelope glycoprotein is composed of three domains, an extracellular one (or ectodomain), a transmembrane one and an intracellular domain (endodomain) [87]. The ectodomain contains three major functional regions: a fusion peptide (FP) located at the amino-terminus of gp41, and two 4-3 heptad repeats (HR) adjacent to the $\mathrm{N}$ - and $\mathrm{C}$-terminal portions of the ectodomain, respectively (Fig. 8) [88]. Just after the binding of gp120 to the coreceptor, the fusion peptide of gp41 is inserted into the cellular membrane, anchoring the virus to the surface of the cell to be infected. Both HR (described in detail further below) consist of mainly hydrophobic residues predicted to form $\alpha$-helices, designed as $\mathrm{N}$ - and C-helix, respectively, which function as essential structures for the oligomerization of gp41 and for conformational changes during the process of membrane fusion [88]. The two HR regions are linked by a peptide presenting a disulfide bond.

To overcome the technical hurdles of crystallizing gp41, it was necessary to truncate the protein to make it stable and soluble. From the resulting structure [87], gp41 was found to have a trimeric core, forming a coiled coil, consisting of parallel $\alpha$-helices corresponding to the N-HR region of gp41. Packed around this coiled coil were three, slightly oblique C-HR $\alpha$-helices, arranged to the inner core to create a trimer of heterodimers, or a six-helix bundle (Fig. 9). The peptide that connects the $\mathrm{N}$ - and C-HR regions is frequently replaced by a 6 -residue (-SGGRGG-) linker. The existing crystallized structures of gp41 can either present the two HR regions linked or not, but in either case the formation of the sixhelix bundle is always observed.

\subsection{Conformational changes of gp41 and fusion membrane model}

The current model for gp41-mediated membrane fusion involves the interaction and conformational changes of several of its distinct domains [87-89]. At least three distinct conformations of the gp41 envelope glycoprotein have been proposed to occur along the conformational changes: the native or pre-fusogenic state, the pre-hairpin intermediate, and the fusion-active or fusogenic state.

Upon gp120-receptor interaction, the gp41 N-terminal fusion peptide is released from its native state conformation and inserts into the target cell membrane. A pre-hairpin intermediate then forms, in which the N-terminal helices form a trimeric-coiled coil and gp41 is extended between the viral and target cell membranes. Following the insertion of the fusion peptides, N- and C-helix undergo an energetically favorable reorganization that results in the formation of a thermostable, six-helix bundle, which represents the fusion-active core of gp41. In this trimer-of-hairpins structure, C-terminal helices pack in an anti-parallel manner into the conserved grooves between adjacent $\mathrm{N}$ helices. Formation of this six-helix bundle pulls the amino and carboxy termini of the gp41 ectodomain into close proximity. The extreme thermostability of the six-helix bundle strongly suggests that once formed, it will not dissociate [90-92]. The resulting juxtaposition of viral and cellular membranes leads to membrane fusion (Fig. 10).

The N-terminal coiled coil formation appears to play a critical role in initiating the gp41 refolding process leading to membrane fusion [94]. In fact, we can see in the presented fusion model that the N-HR region exists in a non-coiled coil conformation in the native state, but forms a coiled coil trimer in the pre-hairpin intermediate and fusogenic hairpin conformations. During this process, the helical ectodomain of gp41 becomes exposed, revealing a prominent hydrophobic cavity on the surface of the gp41 N-terminal coiled coil that was identified as a potential antiviral target [89]. In fact, the approved inhibitor T-20 (enfurvitide) prevents gp41 from folding into a six-helical bundle by binding to the $\mathrm{N}-\mathrm{HR}$ region in the pre-hairpin intermediate, as shown in Fig. 10.

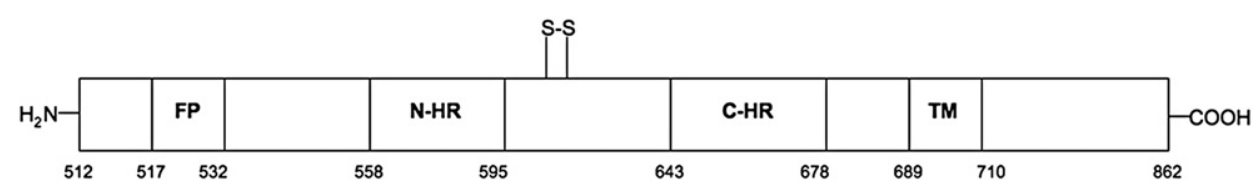

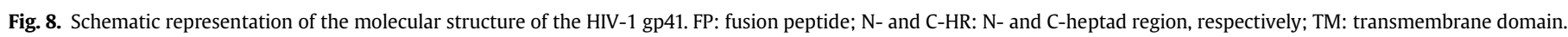



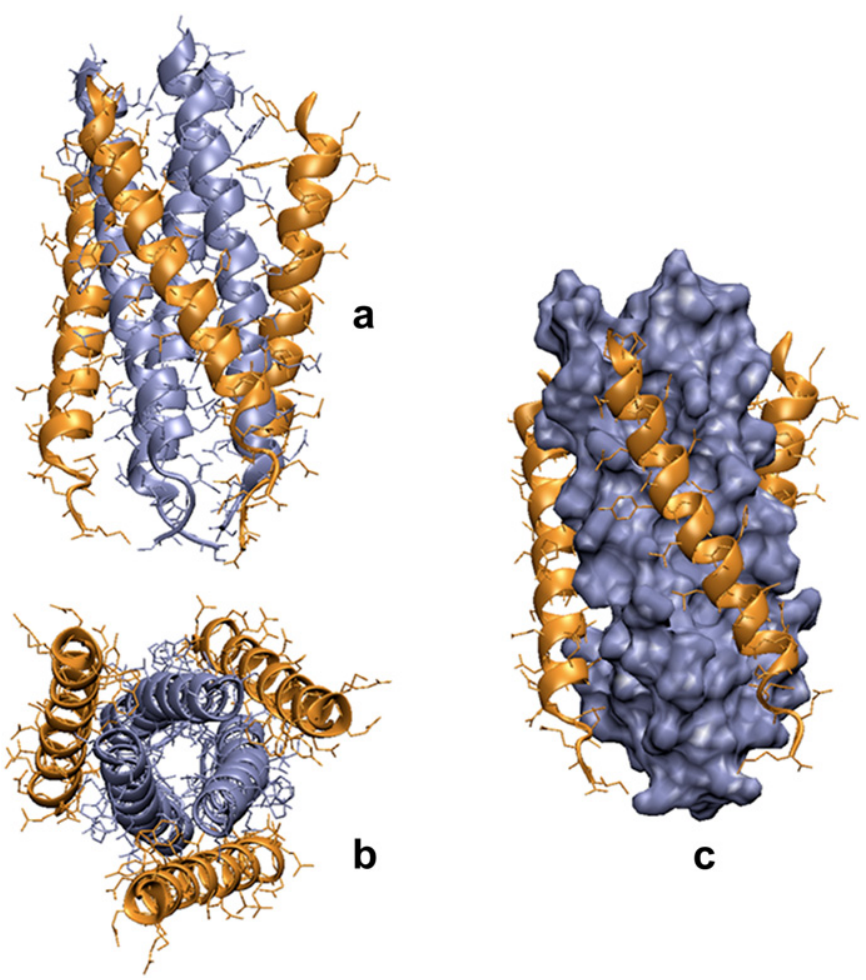

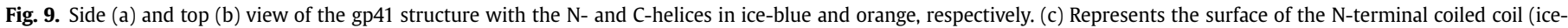

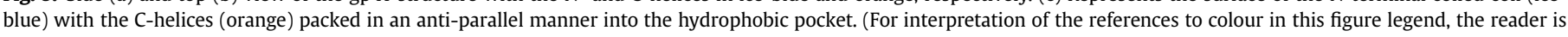
referred to the web version of this article.)

\section{HIV-1 entry inhibitors}

In the "quest" for agents that might have improved antiviral activity, investigators have wondered if equally potent drugs targeting the parts of the virus life cycle that occur outside the cell might be better than drugs targeting events that take place inside infected cells. Why? Anti-HIV drugs that must enter cells to exert their action can be efficiently neutralized by some cells, using primitive and innate self-defense mechanisms such as "efflux pumps" [95], which sense toxins and eject them outside of the cell. Many experts believe that this situation could be an important reason for the viral persistence and evolution in patients on ostensibly potent combination therapies. So, extracellular antiretroviral therapy would completely avoid this problem. Also, any drug working on a separate part of the virus life cycle would have little potential for "cross-resistance" with NRTI, NNRTI or PIs.

\subsection{HIV-1 gp120 inhibitors}

The HIV-1 gp120 envelope protein is an essential component in the multi-tiered viral entry process. Despite the overall genetic heterogeneity of the gp120 glycoprotein, the conserved binding site, which interacts with CD4 receptor, provides an attractive antiviral target. The first attempt was to use soluble CD4 (sCD4) to block virus attachment [96]. Indeed, recombinant SCD4 had shown potent neutralizing activity against a variety of laboratory-adapted HIV strains, but exhibited low effectiveness against primary HIV isolates [97] and poor efficacy in vivo. To improve its pharmacokinetics and binding affinity, Progenics has developed a CD4-immunoglobulin 2 (IgG2) fusion protein, PRO542, in which the Fv portions of heavy and light chains of human IgG2 are replaced by the HIV-binding D1 and D2 domains of human CD4. Unlike sCD4, PRO542 has potent neutralizing activity against diverse primary

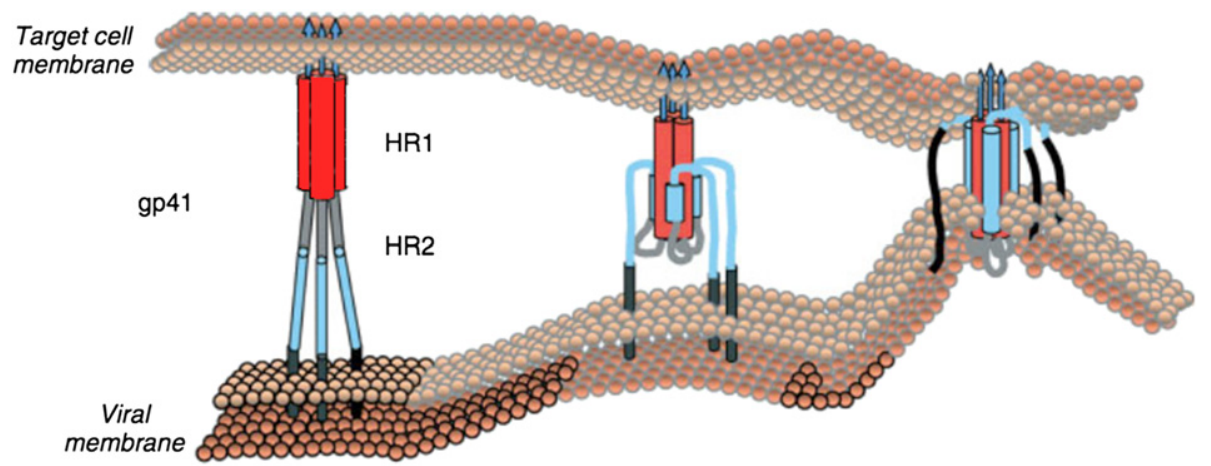

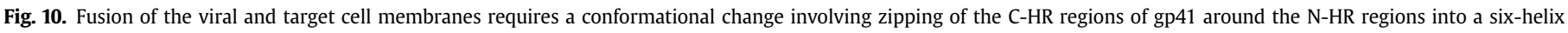
bundle. Adapted from Ref. [93]. 
HIV-1 isolates in vitro and ex vivo. In Phase I and II clinical trials, PRO542 has shown promising efficacy in reducing viral load [98]. The main drawback of this protein drug candidate is requirement of intravenous administration.

Until recently, effective, potent and selective small molecule compounds that inhibit gp120 were difficult to discover. It is known that a series of polyanionic compounds with widely diverging structures and sizes, such as carrageenan (Carraguard), naphthalene sulfonate polymer (PRO 2000), dextran sulfate and cellulose sulfate, can inhibit HIV infection by binding to gp120 and blocking its interaction with CD4 [99]. Although these polymers were unsuccessful in clinical trials as systemic anti-HIV therapeutic agents, because of the presence of certain toxicity and low in vivo efficacy, they are developed in Phase II and III studies as microbicidal candidates for preventing sexual transmission of HIV [100]. However, some of these compounds, as carraguard and cellulose sulfate, have not been approved [101].

A breakthrough in this field has been obtained recently by the report of FP-21399, a bis(disulfonaphthelene) derivative (Fig. 11a), which advanced to Phase I clinical studies for systemic administration as an anti-HIV agent [102]. However, administration once a week during four weeks did not produce a significant reduction in viral load [102]. As this was a limited study, no definitive conclusions could be drawn regarding the antiviral efficiency of FP-21399.

In between, a more drug-like candidate, BMS-378806 (Fig. 11b) has recently been characterized pharmacokinetically, and is currently under investigation. BMS-378806, a 4-methoxy-7azaindole derivative, inhibits infection by both laboratory and clinical HIV-1 strains at nanomolar levels. Lin et al. [103] have demonstrated that BMS-378806-induced mutations are localized at, or near, the CD4-binding pocket of gp120 and BMS-378806 binds to gp120, thereby blocking attachment of the virus to CD4. However, Si et al. [104] have suggested that BMS-378806 does not directly block gp120 from binding to CD4, but instead interferes with CD4-induced conformational rearrangement of gp120-gp41. Despite the controversy, a growing number of studies emerged to support the premise that compounds interact with the
CD4-binding pocket (called Phe43 cavity) of gp120 [81,86,105]. This suggests that more investigations are needed to clarify the mechanism of action of BMS-378806. In animal studies, BMS-378806 has exhibited excellent bioavailability and low protein binding. However, clinical development of BMS-378806 was discontinued and it was replaced by its second-generation analogue BMS488043 (Fig. 11C). This small molecule has demonstrated promising oral bioavailability in Phase I trials, along with a good safety profile, and it is thought that it presents the same mechanism of action as that of BMS-378806 [106]. Given the novelty of oral availability and the promising potent antiviral activity, further development of other members of this class of compounds, namely piperazine derivatives, is certainly warranted. The compounds presented here, targeting the conserved CD4-binding pocket of gp120, have demonstrated clinical efficacy in humans, which validated gp120 as a viable antiviral target.

\subsection{HIV-1 gp41 inhibitors}

HIV-1 gp41 plays a crucial role in the process of HIV-1 fusion. The discovery of the prominent hydrophobic cavity on the surface of the exposed N-HR coiled coil, as possible binding site for gp41 inhibitors, was of extreme importance. Actually, this led to the first thought that both of the $\mathrm{N}$ - and $\mathrm{C}$-terminal regions of gp41 could serve as targets for HIV-1-fusion inhibitors.

In early 1990s, Jiang et al. identified the first potent anti-HIV peptide derived from the HIV-1 gp41 C-HR region, named SJ-2176, which inhibits HIV-1 infection at nanomolar concentrations [107]. The patent on this discovery (US Patent 5,444,044) was later licensed to Trimeris, a pharmaceutical company which, jointly with Roche, developed an analogue peptide T-20 (also known as DP-178, Fuzeon or enfuvirtide) [108]. In clinical studies, T-20 (Fig. 12) showed great promise in suppressing replication of HIV-1 strains by binding to the N-HR region of gp41 (Fig. 9), including those resistant to RTIs and PIs [109]. The drug was licensed by the American FDA as the first member of HIV-1 entry inhibitors for the treatment of HIV-infected individuals and AIDS patients who failed<smiles>COc1cc(N=Nc2c(O)cc3cc(S(=O)(=O)O)cc(NC(=O)c4cccc(Cl)c4Cl)c3c2O)c(OC)cc1N=Nc1c(O)cc2cc(S(=O)(=O)O)cc(NC(=O)c3ccc(Cl)cc3Cl)c2c1O</smiles>

a FP-21399<smiles>COc1ccnc2[nH]cc(C(=O)C(=O)N3CCN(C(=O)c4ccccc4)C[C@@H]3C)c12</smiles>

b BMS-378806<smiles>COc1cnc(OC)c2c(C(=O)C(=O)N3CCN(C(=O)c4ccccc4)CC3)c[nH]c12</smiles>

C BMS- 488043

Fig. 11. Structure of HIV-1 inhibitor FP-21399 (a), BMS-378806 (b) and BMS-488043 (c). 


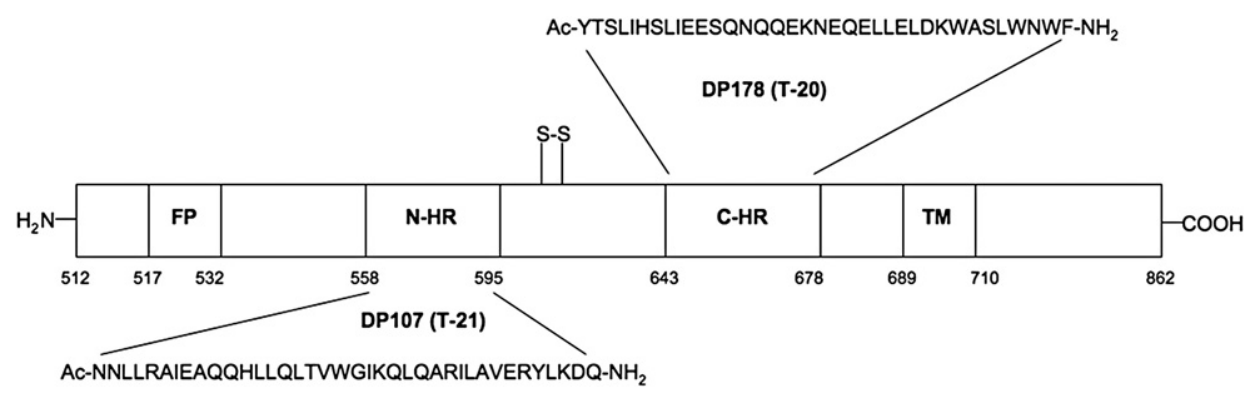

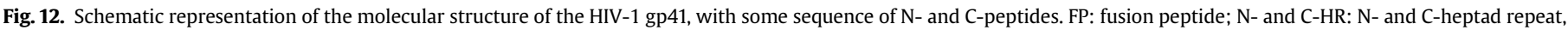
respectively; TM: transmembrane domain. The sequences of the two fusion inhibitors (T-20 and T-21) are shown.

to respond to current anti-retroviral drugs [110]. The secondgeneration HIV-1-fusion inhibitor developed by Trimeris and Roche is T-1249, which contains a pocket-binding sequence and is a more potent HIV-fusion inhibitor. T-1249 has different resistance profiles from T-20 and is active against most T-20-resistant viruses [111]. The first test in HIV-1 infected, treatment experienced patients was favorable, with reductions in viral loads and non-severe side effects [111].

Peptides derived from the N-HR region (Fig. 12) of gp41 were also exploited as possible fusion inhibitors. Wild et al. [112] reported a synthetic N-peptide, designed T-21 (or DP-107) possessing inhibitory activity of HIV-1 mediated cell-cell-fusion. However, monomeric N-HR peptides such as T-21 are prone to aggregation, making them much less potent than $\mathrm{C}-\mathrm{HR}$ peptides [113,114].

Despite the positive results presented above, as drugs, these peptide derivatives have crucial weaknesses: i) sensitivity to protease degradation, ii) poor oral availability, iii) injection site reactions associated with administration of the drug experienced in the majority of patients, and iv) production limited by a complex and highly expensive manufacturing procedure. Therefore, it is essential to develop small non-peptidic HIV-1 entry inhibitors interacting with gp41. However, few have been reported to date.

In an initial effort to develop non-peptide inhibitors of HIV-1 entry, a series of high-throughput screening (HTS) assays were used to search for compounds that might bind in a deep hydrophobic cavity in the inner N-HR peptide core. This way, Jiang et al. [115] identified two N-substituted pyrroles, NB-2 and NB-64 (Fig. 13a and $b$, respectively), that block HIV-1 fusion and entry against both laboratory-adapted and primary HIV-1 strains at low micromolar levels. More recently, Zhou et al. [116] also performed a highthroughput screening assay combined with structure-based design, which led to the discovery of indole derivatives (Fig. 13d) as gp41 inhibitors at low micromolar levels.

Betulinic acid (Fig. 13c), a terpenoid isolated from the methyl alcohol extract of the leaves of Syzigium claviflorum, was found to have a potent inhibitory activity against HIV-1, with an $\mathrm{IC}_{50}$ of $1.4 \mu \mathrm{M}$ [117]. Many different derivatives of this compound were then reported, and shown to interact with the postbinding virus-cell fusion process, more precisely with gp41 [118-120].<smiles>Cc1ccc(C)n1-c1ccc(C(=O)O)c(O)c1</smiles>

a) NB-2<smiles>Cc1ccc(C)n1-c1ccc(Cl)c(C(=O)O)c1</smiles>

b) NB-64<smiles>CCC1CCCC1</smiles>

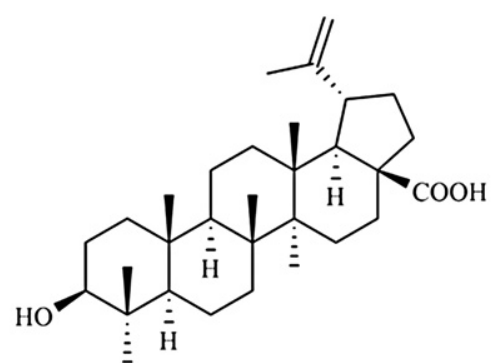

c) Betulinic acid<smiles>O=C(O)c1cccc(Cc2ccc3cc[nH]c3c2)c1</smiles>

d) 3-((1H-indol-6-yl)methyl)benzoic acid<smiles></smiles>

Fig. 13. Some non-peptidic inhibitors of gp41: NB-2 (a), NB-64 (b), betulinic acid (c), 3-((1H-indol-6-yl)methyl)benzoic acid (d), ADS-J1 (e) and C7M34M42p30 (f). 
Another molecule shown to bind to gp41 is the azo dye ADS-J1 (Fig. 13e), which also exhibited antiviral activity in vitro [121].

Ferrer et al., used a short C-HR peptide as a scaffold for attaching a non-peptide combinatorial library onto its $\mathrm{N}$ terminus. The library was screened against an engineered trimer of $\mathrm{N}-\mathrm{HR}$ peptides, and a hybrid ligand (C7M34M42p30; Fig. 13f), composed of a synthetic moiety linked to the C-HR peptide, that was able to inhibit HIV-1 envelope-mediated cell-cell fusion was selected [122]. Further optimization of the non-peptide moiety is envisioned as a route to a stand-alone, small molecule fusion inhibitor.

\subsection{Challenges in the development of entry inhibitors}

The emerging class of entry inhibitors holds considerable potential for the treatment of patients with HIV-1 infection, particularly those having viruses that have resistance to RT and protease inhibitors. However, while progress has been made in understanding HIV-1 entry process, a number of critical gaps remain. In fact, structures of gp120 bound to CD4 and the structure of the core of gp41 in the post-fusion state have been solved. But, determination of the structures of CD4 inhibitors bound to gp120, the conformation of gp41 prior to fusion, and the structure of the native trimer remains elusive. Additionally, structure of the gp120co-receptor interaction is also unavailable. So, a better understanding of how entry inhibitors bind to both HIV-1 glycoproteins, gp120 and gp41, should make it possible to develop more potent and broadly cross-reactive inhibitors, as well as to design drugs with "strategic flexibility" that might enable them to bind to a somewhat variable target, such as HIV-1 gp120.

\section{Molecular modeling studies of gp120 and gp41}

We have seen that it is essential to develop compounds with higher effectiveness and lower side effects that can prevent early steps of HIV-1 infection. Several types of work have been described, of which we give here a few examples. However, concerning the molecular modeling studies of HIV-1 entry, three major goals can be highlighted.

Thermodynamic data show that gp120 undergoes large conformational changes from the free form to the CD4-bound state [123]. However, the free form or uncomplexed HIV gp120 is still unavailable. The lack of knowledge of the HIV gp120 conformation in its free form has limited the development of efficient therapeutic agents. Since a complete three-dimensional structure of gp120 is not available yet, neither from X-ray crystallographic or NMR studies, one of the goals to be reached by a computational approach is the completion of the gp120 amino acid sequence and its structural optimization. The same occurs in the case of gp41. Indeed there have been numerous crystal structures of the HIV-1 gp41 ectodomain [87,124], the extracellular region of gp41 that binds to gp120, in isolation, but no structural information is available for the other domains of the viral protein. Therefore, homology modeling $[125,126]$, has been used in an effort to better understand the molecular interactions and roles of gp41 loop, fusion peptide (FP) and transmembrane (TM) domains. In addition to the computational approach referred above, docking techniques and molecular dynamics studies were also used either to screen molecules from databases or to determine binding modes to understand key structural features and interactions, which are expected to provide valuable information for the design of efficient inhibitors.

\section{1. $g p 120$}

One of the first computational studies on gp120 was performed by Gabriel et al., and consisted on the description, at atomic level, of a truncated HIV-1 gpl20 structure derived by molecular dynamics and calculation of potential energy [127]. To this model they docked the CD4 receptor and highlighted that the primary mechanism of recognition and binding corresponds to the insertion of the solvent-accessible Phe43 of CD4 into a gp120 solvent-accessible acceptor cavity formed by Trp427, Tyr235 and Asn230.

The completion of the gp120 amino acid sequence and its structural optimization was achieved by Manetti et al. [126], employing both MD simulations and homology modeling. Also, the group of Liu et al., built the homology models of gp120 with loops V3 and V4 in the CD4-complex and CD4-unbound states, and models of the S375W and I423P mutants in the CD4-unbound states [125]. This permitted to quantitatively distinguish the preference for conformational transitions between states of the gp120 mutants and further to ascertain what kind of conformational state do mutants prefer to adopt.

Previously, molecular dynamics (MD) simulations show that CD4-bound gp120 only relaxes to a limited extent upon removal of CD4 even under raised temperature, with the exception of the bridging sheet $[128,129]$. However, it was not clear whether the three-dimensional structure can be maintained or how it will change its conformation when the bridging sheet is further separated from the core.

More recently, the same group of Pan et al. examined the free energy landscape for the conformational change of the bridging sheet starting from the CD4-bound state using potential mean force (PMF) MD simulations [130]. The results show that it is unlikely for the whole bridging sheet to fall apart from the core domain without significant rearrangements of the inner or outer domains. On the other hand, the $\beta 2 / 3$ part of the bridging sheet displayed high flexibility and can switch its conformations between the folded and unfolded states with a small free energy barrier.

Kong et al. used molecular docking in conjunction with molecular dynamics simulation, accommodating the receptor's flexibility, to explore the binding mode between BMS-378806 and gp120. The conclusion was that BMS-378806 inserts the azaindole ring deeply into the Phe 43 cavity and makes contact with a number of residues in the cavity, on the cavity and near the cavity [131].

\section{2. $g p 41$}

Concerning the structural information for the loop, FP and TM domains of the viral protein, Caffrey et al. presented a model for the structure of the HIV-1 gp41 loop [132], which is based on the solution structure of the SIV gp41 ectodomain [133]. The resulting model presents the first structural information for the HIV gp41 loop, which has been implicated to play a direct role in binding to gp120 and C1q of the complement system.

Kamath et al. studied the structures of the16-residue FP domain of HIV-1 gp41 fusion protein, two of its mutants, and a shortened peptide (5-16) by MD simulations in an explicit palmitoyloleoylphosphoethanolamine bilayer [134]. This was the first demonstration by explicit molecular dynamics of the oblique insertion of the fusion domain into lipid bilayers, and provided correlation between the mode of insertion and the fusogenic activity of these peptides.

Kim et al. used also MD to analyze and compare the conformations of monomeric and trimeric forms of the TM domain. The results suggested that formation of the three-helix bundle of the TM domain may play a role in the trimerization of gp41, thought to occur during the virus-cell membrane fusion process [135].

Martins do Canto et al. carried out extensive MD simulations to investigate the structure and conformational behavior of T-1249 and T-20 in water [136]. Their findings suggested that these peptides may assume not only one, but several possible sets of structures in solution, some of which more adequate to interact 
with the solvent, whereas others might be better suited to interact with cell membranes. They also verified that T-1249 displayed considerably larger $\alpha$-helical structure than T-20.

Debnath et al. used molecular docking techniques to screen a database of 20000 organic molecules [121]. They found 16 compounds with the best fit for docking into the hydrophobic cavity within the gp41 core. Further testing of these compounds by virus inhibition assays discerned two compounds (ADS-J1 and ADS$\mathrm{J} 2$; see Fig. 13e) having inhibitory activity at micromolar concentrations on the formation of the gp41 core structure and on HIV-1 infection. Another group, Jiang et al., also used computer-aided molecular docking analysis to show that NB-2 and NB-64 (see Fig. 13a and b) bind to the gp41 hydrophobic cavity region through hydrophobic and ionic interactions and blocks the formation of the fusion-active gp41 core [115].

Strockbine et al. used all-atom MD simulations followed by Molecular Mechanics Generalized Born Surface Area (MM-GBSA) analyses to probe structure-activity relationships (SAR) for six C34 peptides [137]. Their results show that differential association of Cpeptides with HIV gp41 is driven solely by changes within the conserved pocket. Also, they identified a highly populated p-type hydrogen bond, which formed between $G \ln 575$ on the receptor and the aromatic ring of peptide ligand Phe631.

Liu et al. found that several tea polyphenols, especially those with the galloyl moiety, could inhibit HIV-1 replication with multiple mechanisms of action [138]. Later, the same group performed computer-aided molecular docking analyses to explore the possibility of binding of these compounds to gp41 [139]. The results indicated that these tea polyphenols, theaflavin-3,3'-digallate (TF3) as an example, may bind to the highly conserved hydrophobic pocket on the surface of the central trimeric-coiled coil formed by the N-terminal heptad repeats of gp41.

In a recent experimental study it was found that olive leaf extract (OLE) has anti-HIV activity by blocking the HIV virus entry to host [140]. Consequently, Bao et al. performed molecular modeling studies on these compounds and found a number of possible binding modes by docking oleuropein and its metabolites onto the hydrophobic pocket on gp41 [141]. Also, they obtained detailed OLE-gp41 binding interactions and free energies of binding through MD simulations and MM-PBSA calculation [141]. This computational study complemented the corresponding experimental investigation and helped in establishing a good starting point for further refinement of OLE-based gp41 inhibitors.

\section{Conclusions}

Presently, almost three decades after it was firstly presented to mankind, AIDS remains one of the major threatening diseases known and current treatment regimens are undetermined by poor long-term effects and high costs. The current treatments for anti-HIV therapy are primarily focused on the protease and reverse transcriptase of the virus and their effectiveness is mainly reduced due to severe side effects and the emergence of drug-resistant HIV strains. Therefore, there is an urgent need for the development of improved drugs targeting new and potential targets of the virus. This can be achieved by the inhibition of viral surface proteins such as gp120 or gp41 and, consequently, by blocking the entry process of HIV-1. Indeed, the discovery and successful development of HIV-1 entry inhibitors proves viral entry as a viable target for therapeutic intervention in HIV1 patients. In the present review, the structural details of gp120 and gp41 that permit HIV-1 to gain access to the inside of our cells, their mechanism of action and inhibitors were overviewed. A special attention was paid to several molecular modeling studies to identify new entry inhibitors and lead optimization.
One of the major computational approaches employed in the development of these bioactive compounds consists of the completion of the gp120 and gp41 amino acid sequences and their structural optimization by homology modeling. Along with this method, docking and molecular dynamics provide a better understanding of how entry inhibitors bind to both HIV-1 glycoproteins, in order to develop more potent and broadly cross-reactive inhibitors. It is apparent that the inhibition of virus entry displays diverse mechanistic opportunities for therapeutic intervention at an early stage in the virus life cycle that has yet to be completely and efficiently exploited.

\section{References}

[1] First report of AIDS, MMWR Morb. Mortal. Wkly. Rep. 50 (2001) 429.

[2] F. Barre-Sinoussi, J.C. Chermann, F. Rey, M.T. Nugeyre, S. Chamaret, J. Gruest, C. Dauguet, C. Axler-Blin, F. Vezinet-Brun, C. Rouzioux, W. Rozenbaum, L. Montagnier, Isolation of a T-lymphotropic retrovirus from a patient at risk for acquired immune deficiency syndrome (AIDS), Science 220 (1983) $868-871$.

[3] R.C. Gallo, S.Z. Salahuddin, M. Popovic, G.M. Shearer, M. Kaplan, B.F. Haynes, T.J. Palker, R. Redfield, J. Oleske, B. Safai, et al., Frequent detection and isolation of cytopathic retroviruses (HTLV-III) from patients with AIDS and at risk for AIDS, Science 224 (1984) 500-503.

[4] J.A. Levy, A.D. Hoffman, S.M. Kramer, J.A. Landis, J.M. Shimabukuro, L.S. Oshiro, Isolation of lymphocytopathic retroviruses from San Francisco patients with AIDS, Science 225 (1984) 840-842.

[5] J. Coffin, A. Haase, J.A. Levy, L. Montagnier, S. Oroszlan, N. Teich, H. Temin, K. Toyoshima, H. Varmus, P. Vogt, et al., Human immunodeficiency viruses, Science 232 (1986) 697

[6] http://www.unaids.org/en/, in August 2010.

[7] L. Ratner, HIV life cycle and genetic approaches, Perspect. Drug Dis. Des. 1 (1993) 3-22.

[8] F. Clavel, D. Guetard, F. Brun-Vezinet, S. Chamaret, M.A. Rey, M.O. SantosFerreira, A.G. Laurent, C. Dauguet, C. Katlama, C. Rouzioux, et al., Isolation of a new human retrovirus from West African patients with AIDS, Science 233 (1986) 343-346.

[9] L.A. Los Alamos National Laboratory, NM. Human retroviruses and aids 1999: a compilation and analysis of nucleic acid and amino acid sequences http:// hiv-web.lanl.gov

[10] D.L. Robertson, J.P. Anderson, J.A. Bradac, J.K. Carr, B. Foley, R.K. Funkhouser, F. Gao, B.H. Hahn, M.L. Kalish, C. Kuiken, G.H. Learn, T. Leitner, F. McCutchan, S. Osmanov, M. Peeters, D. Pieniazek, M. Salminen, P.M. Sharp, S. Wolinsky, B. Korber, HIV-1 nomenclature proposal, Science 288 (2000) 55-56.

[11] D.L. Robertson, B.H. Hahn, P.M. Sharp, Recombination in AIDS viruses, J. Mol. Evol. 40 (1995) 249-259.

[12] A. Alaeus, T. Leitner, K. Lidman, J. Albert, Most HIV-1 genetic subtypes have entered Sweden, AIDS 11 (1997) 199-202.

[13] A.W. Artenstein, J. Coppola, A.E. Brown, J.K. Carr, E. Sanders-Buell, E. Galbarini, J.R. Mascola, T.C. VanCott, P. Schonbrood, F.E. McCutchan, et al., Multiple introductions of HIV-1 subtype E into the western hemisphere, Lancet 346 (1995) 1197-1198.

[14] S.K. Brodine, J.R. Mascola, P.J. Weiss, S.I. Ito, K.R. Porter, A.W. Artenstein, F.C. Garland, F.E. McCutchan, D.S. Burke, Detection of diverse HIV-1 genetic subtypes in the USA, Lancet 346 (1995) 1198-1199.

[15] L. Heyndrickx, W. Janssens, S. Coppens, K. Vereecken, B. Willems, K. Fransen, R. Colebunders, M. Vandenbruaene, G. van der Groen, HIV type 1 C2V3 env diversity among Belgian individuals, AIDS Res. Hum. Retroviruses 14 (1998) 1291-1296.

[16] L.M. Janini, A. Tanuri, M. Schechter, J.M. Peralta, A.C. Vicente, N. Dela Torre, N.J. Pieniazek, C.C. Luo, A. Ramos, V. Soriano, G. Schochetman, M.A. Rayfield, D. Pieniazek, Horizontal and vertical transmission of human immunodeficiency virus type 1 dual infections caused by viruses of subtypes B and C, J. Infect. Dis. 177 (1998) 227-231.

[17] C. Montavon, C. Toure-Kane, F. Liegeois, E. Mpoudi, A. Bourgeois, L. Vergne, J.L. Perret, A. Boumah, E. Saman, S. Mboup, E. Delaporte, M. Peeters, Most env and gag subtype a HIV-1 viruses circulating in West and West Central Africa are similar to the prototype AG recombinant virus IBNG, J. Acquired Immune Defic. Syndr. 23 (2000) 363-374.

[18] N. Vidal, M. Peeters, C. Mulanga-Kabeya, N. Nzilambi, D. Robertson, W. Ilunga, H. Sema, K. Tshimanga, B. Bongo, E. Delaporte, Unprecedented degree of human immunodeficiency virus type 1 (HIV-1) group M genetic diversity in the Democratic Republic of Congo suggests that the HIV-1 pandemic originated in Central Africa, J. Virol. 74 (2000) 10498-10507.

[19] F. Gao, E. Bailes, D.L. Robertson, Y. Chen, C.M. Rodenburg, S.F. Michael, L.B. Cummins, L.O. Arthur, M. Peeters, G.M. Shaw, P.M. Sharp, B.H. Hahn, Origin of HIV-1 in the chimpanzee Pan troglodytes troglodytes, Nature 397 (1999) 436-441.

[20] S. Corbet, M.C. Muller-Trutwin, P. Versmisse, S. Delarue, A. Ayouba, J. Lewis, S. Brunak, P. Martin, F. Brun-Vezinet, F. Simon, F. Barre-Sinoussi, P. Mauclere, 
Env sequences of simian immunodeficiency viruses from chimpanzees in Cameroon are strongly related to those of human immunodeficiency virus group N from the same geographic area, J. Virol. 74 (2000) 529-534.

[21] B.H. Hahn, G.M. Shaw, K.M. De Cock, P.M. Sharp, AIDS as a zoonosis: scientific and public health implications, Science 287 (2000) 607-614.

[22] F. Simon, P. Mauclere, P. Roques, I. Loussert-Ajaka, M.C. Muller-Trutwin, S. Saragosti, M.C. Georges-Courbot, F. Barre-Sinoussi, F. Brun-Vezinet, Identification of a new human immunodeficiency virus type 1 distinct from group M and group O, Nat. Med. 4 (1998) 1032-1037.

[23] A.J. Nahmias, J. Weiss, X. Yao, F. Lee, R. Kodsi, M. Schanfield, T. Matthews, D. Bolognesi, D. Durack, A. Motulsky, et al., Evidence for human infection with an HTLV III/LAV-like virus in Central Africa, 1959, Lancet 1 (1986) 1279-1280.

[24] B. Korber, M. Muldoon, J. Theiler, F. Gao, R. Gupta, A. Lapedes, B.H. Hahn, S. Wolinsky, T. Bhattacharya, Timing the ancestor of the HIV-1 pandemic strains, Science 288 (2000) 1789-1796.

[25] A.T. Haase, Population biology of HIV-1 infection: viral and CD4+ T cell demographics and dynamics in lymphatic tissues, Annu. Rev. Immunol. 17 (1999) 625-656.

[26] F.S. De Silva, D.S. Venturini, E. Wagner, P.R. Shank, S. Sharma, CD4-independent infection of human B cells with HIV type 1: detection of unintegrated viral DNA, AIDS Res. Hum. Retroviruses 17 (2001) 1585-1598.

[27] P.R. Gorry, C. Ong, J. Thorpe, S. Bannwarth, K.A. Thompson, A. Gatignol, S.L. Vesselingh, D.F. Purcell, Astrocyte infection by HIV-1: mechanisms of restricted virus replication, and role in the pathogenesis of HIV-1-associated dementia, Curr. HIV Res. 1 (2003) 463-473.

[28] Y. Liu, H. Liu, B.O. Kim, V.H. Gattone, J. Li, A. Nath, J. Blum, J.J. He, CD4independent infection of astrocytes by human immunodeficiency virus type 1: requirement for the human mannose receptor, J. Virol. 78 (2004) $4120-4133$.

[29] S.G. Kitchen, C.H. Uittenbogaart, J.A. Zack, Mechanism of human immunodeficiency virus type 1 localization in CD4-negative thymocytes: differentiation from a CD4-positive precursor allows productive infection, J. Virol. 71 (1997) 5713-5722.

[30] W.J. Livingstone, M. Moore, D. Innes, J.E. Bell, P. Simmonds, Frequent infection of peripheral blood CD8-positive T-lymphocytes with HIV-1. Edinburgh Heterosexual Transmission Study Group, Lancet 348 (1996) 649-654.

[31] S. Gummuluru, M. Rogel, L. Stamatatos, M. Emerman, Binding of human immunodeficiency virus type 1 to immature dendritic cells can occur independently of DC-SIGN and mannose binding C-type lectin receptors via a cholesterol-dependent pathway, J. Virol. 77 (2003) 12865-12874.

[32] L. Al-Harthi, L.J. Guilbert, J.A. Hoxie, A. Landay, Trophoblasts are productively infected by CD4-independent isolate of HIV type 1, AIDS Res. Hum. Retroviruses 18 (2002) 13-17.

[33] T.C. Quinn, Acute primary HIV infection, J. Am. Med. Assoc. 278 (1997) $58-62$.

[34] E.S. Daar, T. Moudgil, R.D. Meyer, D.D. Ho, Transient high levels of viremia in patients with primary human immunodeficiency virus type 1 infection, N. Engl. J. Med. 324 (1991) 961-964.

[35] D.D. Ho, A.U. Neumann, A.S. Perelson, W. Chen, J.M. Leonard, M. Markowitz, Rapid turnover of plasma virions and CD4 lymphocytes in HIV-1 infection, Nature 373 (1995) 123-126.

[36] X. Wei, S.K. Ghosh, M.E. Taylor, V.A. Johnson, E.A. Emini, P. Deutsch, J.D. Lifson, S. Bonhoeffer, M.A. Nowak, B.H. Hahn, et al., Viral dynamics in human immunodeficiency virus type 1 infection, Nature 373 (1995) 117-122.

[37] M. Piatak Jr., M.S. Saag, L.C. Yang, S.J. Clark, J.C. Kappes, K.C. Luk, B.H. Hahn, G.M. Shaw, J.D. Lifson, High levels of HIV-1 in plasma during all stages of infection determined by competitive PCR, Science 259 (1993) 1749-1754.

[38] J.S. Montaner, R. Hogg, E. Wood, T. Kerr, M. Tyndall, A.R. Levy, P.R. Harrigan, The case for expanding access to highly active antiretroviral therapy to curb the growth of the HIV epidemic, Lancet 368 (2006) 531-536.

[39] J.S. Moore, F. Rahemtulla, L.W. Kent, S.D. Hall, M.R. Ikizler, P.F. Wright, H.H. Nguyen, S. Jackson, Oral epithelial cells are susceptible to cell-free and cell-associated HIV-1 infection in vitro, Virology 313 (2003) 343-353.

[40] T.C. Quinn, M.J. Wawer, N. Sewankambo, D. Serwadda, C. Li, F. WabwireMangen, M.O. Meehan, T. Lutalo, R.H. Gray, Viral load and heterosexual transmission of human immunodeficiency virus type 1. Rakai Project Study Group, N. Engl. J. Med. 342 (2000) 921-929.

[41] M.S. Cohen, HIV and sexually transmitted diseases: lethal synergy, Top. HIV Med. 12 (2004) 104-107.

[42] D.J. Hunter, B.N. Maggwa, J.K. Mati, P.M. Tukei, S. Mbugua, Sexual behavior, sexually transmitted diseases, male circumcision and risk of HIV infection among women in Nairobi, Kenya, AIDS 8 (1994) 93-99.

[43] E.L. Korenromp, R.G. White, K.K. Orroth, R. Bakker, A. Kamali, D. Serwadda, R.H. Gray, H. Grosskurth, J.D. Habbema, R.J. Hayes, Determinants of the impact of sexually transmitted infection treatment on prevention of HIV infection: a synthesis of evidence from the Mwanza, Rakai, and Masaka intervention trials, J Infect Dis 191 (Suppl 1) (2005) S168-S178.

[44] F.A. Plummer, J.N. Simonsen, D.W. Cameron, J.O. Ndinya-Achola, J.K. Kreiss, M.N. Gakinya, P. Waiyaki, M. Cheang, P. Piot, A.R. Ronald, et al., Cofactors in male-female sexual transmission of human immunodeficiency virus type 1 , J. Infect. Dis. 163 (1991) 233-239.

[45] P.S. Reichelderfer, R.W. Coombs, D.J. Wright, J. Cohn, D.N. Burns, S. Cu-Uvin, P.A. Baron, M.H. Coheng, A.L. Landay, S.K. Beckner, S.R. Lewis, A.A. Kovacs,
Effect of menstrual cycle on HIV-1 levels in the peripheral blood and genital tract. WHS 001 Study Team, AIDS 14 (2000) 2101-2107.

[46] G.R. Yeaman, A.L. Howell, S. Weldon, D.J. Demian, J.E. Collins, D.M. O'Connell S.N. Asin, C.R. Wira, M.W. Fanger, Human immunodeficiency virus receptor and coreceptor expression on human uterine epithelial cells: regulation of expression during the menstrual cycle and implications for human immunodeficiency virus infection, Immunology 109 (2003) 137-146.

[47] S. Bour, K. Strebel, HIV accessory proteins: multifunctional components of a complex system, Adv. Pharmacol. 48 (2000) 75-120.

[48] A. Okumura, T. Alce, B. Lubyova, H. Ezelle, K. Strebel, P.M. Pitha, HIV-1 accessory proteins VPR and Vif modulate antiviral response by targeting IRF3 for degradation, Virology 373 (2008) 85-97.

[49] S. Bour, K. Strebel, The HIV-1 Vpu protein: a multifunctional enhancer of viral particle release, Microbes Infect. 5 (2003) 1029-1039.

[50] J.L. Foster, J.V. Garcia, HIV-1 Nef: at the crossroads, Retrovirology 5 (2008) 84.

[51] National Center for Biotechnology Information (N.C.B.I.), Pubmed. http:// www.ncbi.nlm.nih.gov/pubmed?term=HIV\%20or\%20AIDS, in January 2011.

[52] W.C. Greene, Z. Debyser, Y. Ikeda, E.O. Freed, E. Stephens, W. Yonemoto, R.W. Buckheit, J.A. Este, T. Cihlar, Novel targets for HIV therapy, Antivir. Res. 80 (2008) 251-265.

[53] S. Broder, The development of antiretroviral therapy and its impact on the HIV-1/AIDS pandemic, Antivir. Res. 85 (2010) 1-18.

[54] J.A. Este, T. Cihlar, Current status and challenges of antiretroviral research and therapy, Antivir. Res. 85 (2010) 25-33.

[55] J.C. Tilton, R.W. Doms, Entry inhibitors in the treatment of HIV-1 infection, Antivir. Res. 85 (2010) 91-100.

[56] S. Broder, Twenty-five years of translational medicine in antiretroviral therapy: promises to keep, Sci. Transl Med. 2 (2010) pp. 39ps33.

[57] E. De Clercq, Antiviral drug discovery: ten more compounds, and ten more stories (part B), Med. Res. Rev. 29 (2009) 571-610.

[58] E. De Clercq, Another ten stories in antiviral drug discovery (part C): "Old" and "new" antivirals, strategies, and perspectives, Med. Res. Rev. 29 (2009) $611-645$.

[59] E. De Clercq, Anti-HIV drugs: 25 compounds approved within 25 years after the discovery of HIV, Int. J. Antimicrob. Agents 33 (2009) 307-320.

[60] D. Robertson, US FDA approves new class of HIV therapeutics, Nat. Biotechnol. 21 (2003) 470-471.

[61] B. Grinsztejn, B.Y. Nguyen, C. Katlama, J.M. Gatell, A. Lazzarin, D. Vittecoq C.J. Gonzalez, J. Chen, C.M. Harvey, R.D. Isaacs, Safety and efficacy of the HIV1 integrase inhibitor raltegravir (MK-0518) in treatment-experienced patients with multidrug-resistant virus: a phase II randomised controlled trial, Lancet 369 (2007) 1261-1269.

[62] G. Fatkenheuer, A.L. Pozniak, M.A. Johnson, A. Plettenberg, S. Staszewski, A.I. Hoepelman, M.S. Saag, F.D. Goebel, J.K. Rockstroh, B.J. Dezube, T.M. Jenkins, C. Medhurst, J.F. Sullivan, C. Ridgway, S. Abel, I.T. James, M. Youle, E. van der Ryst, Efficacy of short-term monotherapy with maraviroc, a new CCR5 antagonist, in patients infected with HIV-1, Nat. Med. 11 (2005) 1170-1172.

[63] P.G. Yeni, S.M. Hammer, M.S. Hirsch, M.S. Saag, M. Schechter, C.C. Carpenter M.A. Fischl, J.M. Gatell, B.G. Gazzard, D.M. Jacobsen, D.A. Katzenstein, J.S. Montaner, D.D. Richman, R.T. Schooley, M.A. Thompson, S. Vella, P.A. Volberding, Treatment for adult HIV infection: 2004 recommendations of the International AIDS Society-USA panel, J. Am. Med. Assoc. 292 (2004) 251-265.

[64] G.M. Lucas, R.E. Chaisson, R.D. Moore, Highly active antiretroviral therapy in a large urban clinic: risk factors for virologic failure and adverse drug reactions, Ann. Intern. Med. 131 (1999) 81-87.

[65] S. Yerly, L. Kaiser, E. Race, J.P. Bru, F. Clavel, L. Perrin, Transmission of antiretroviral-drug-resistant HIV-1 variants, Lancet 354 (1999) 729-733.

[66] T.W. Chun, R.T. Davey Jr., D. Engel, H.C. Lane, A.S. Fauci, Re-emergence of HIV after stopping therapy, Nature 401 (1999) 874-875.

[67] D. Finzi, M. Hermankova, T. Pierson, L.M. Carruth, C. Buck, R.E. Chaisson, T.C. Quinn, K. Chadwick, J. Margolick, R. Brookmeyer, J. Gallant, M. Markowitz, D.D. Ho, D.D. Richman, R.F. Siliciano, Identification of a reservoir for HIV-1 in patients on highly active antiretroviral therapy, Science 278 (1997) 1295-1300.

[68] M.D. Miller, D.J. Hazuda, HIV resistance to the fusion inhibitor enfuvirtide: mechanisms and clinical implications, Drug Resist. Updates 7 (2004) 89-95.

[69] A. McKnight, R.A. Weiss, Blocking the docking of HIV-1, Proc. Natl. Acad. Sci. U.S.A. 100 (2003) 10581-10582.

[70] E.E. Perez, J. Wang, J.C. Miller, Y. Jouvenot, K.A. Kim, O. Liu, N. Wang, G. Lee V.V. Bartsevich, Y.L. Lee, D.Y. Guschin, I. Rupniewski, A.J. Waite, C. Carpenito, R.G. Carroll, J.S. Orange, F.D. Urnov, E.J. Rebar, D. Ando, P.D. Gregory, J.L. Riley, M.C. Holmes, C.H. June, Establishment of HIV-1 resistance in CD4+ T cells by genome editing using zinc-finger nucleases, Nat. Biotechnol. 26 (2008) 808-816.

[71] M.M. Lederman, R.S. Veazey, R. Offord, D.E. Mosier, J. Dufour, M. Mefford M. Piatak Jr., J.D. Lifson, J.R. Salkowitz, B. Rodriguez, A. Blauvelt, O. Hartley, Prevention of vaginal SHIV transmission in rhesus macaques through inhibition of CCR5, Science 306 (2004) 485-487.

[72] R. Liu, W.A. Paxton, S. Choe, D. Ceradini, S.R. Martin, R. Horuk, M.E. MacDonald, H. Stuhlmann, R.A. Koup, N.R. Landau, Homozygous defect in HIV-1 coreceptor accounts for resistance of some multiply-exposed individuals to HIV-1 infection, Cell 86 (1996) 367-377. 
[73] Y. Huang, W.A. Paxton, S.M. Wolinsky, A.U. Neumann, L. Zhang, T. He, S. Kang D. Ceradini, Z. Jin, K. Yazdanbakhsh, K. Kunstman, D. Erickson, E. Dragon, N.R. Landau, J. Phair, D.D. Ho, R.A. Koup, The role of a mutant CCR5 allele in HIV 1 transmission and disease progression, Nat. Med. 2 (1996) 1240-1243.

[74] M. Samson, F. Libert, B.J. Doranz, J. Rucker, C. Liesnard, C.M. Farber, S. Saragosti, C. Lapoumeroulie, J. Cognaux, C. Forceille, G. Muyldermans, C. Verhofstede, G. Burtonboy, M. Georges, T. Imai, S. Rana, Y. Yi, R.J. Smyth, R.G. Collman, R.W. Doms, G. Vassart, M. Parmentier, Resistance to HIV-1 infection in caucasian individuals bearing mutant alleles of the CCR-5 chemokine receptor gene, Nature 382 (1996) 722-725.

[75] R. Horuk, Chemokine receptor antagonists: overcoming developmental hurdles, Nat. Rev. Drug Discov. 8 (2009) 23-33.

[76] B.R. Starcich, B.H. Hahn, G.M. Shaw, P.D. McNeely, S. Modrow, H. Wolf E.S. Parks, W.P. Parks, S.F. Josephs, R.C. Gallo, et al., Identification and characterization of conserved and variable regions in the envelope gene of HTLVIII/LAV, the retrovirus of AIDS, Cell 45 (1986) 637-648.

[77] C.K. Leonard, M.W. Spellman, L. Riddle, R.J. Harris, J.N. Thomas, T.J. Gregory, Assignment of intrachain disulfide bonds and characterization of potentia glycosylation sites of the type 1 recombinant human immunodeficiency virus envelope glycoprotein (gp120) expressed in Chinese hamster ovary cells, J. Biol. Chem. 265 (1990) 10373-10382.

[78] R. Wyatt, P.D. Kwong, W.A. Hendrickson, J. Sodroski, Structure of the core of the HIV-1 gp120 exterior envelope glycoprotein. http://www.hiv.lanl.gov content/sequence/HIV/COMPENDIUM/1998/III/Sodroski.pdf (1998) (accessed January 2011)

[79] P.D. Kwong, R. Wyatt, J. Robinson, R.W. Sweet, J. Sodroski, W.A. Hendrickson, Structure of an HIV gp120 envelope glycoprotein in complex with the CD4 receptor and a neutralizing human antibody, Nature 393 (1998) 648-659.

[80] C.D. Rizzuto, R. Wyatt, N. Hernandez-Ramos, Y. Sun, P.D. Kwong, W.A. Hendrickson, J. Sodroski, A conserved HIV gp120 glycoprotein structure involved in chemokine receptor binding, Science 280 (1998) 1949-1953.

[81] B. Chen, E.M. Vogan, H. Gong, J.J. Skehel, D.C. Wiley, S.C. Harrison, Structure of an unliganded simian immunodeficiency virus gp120 core, Nature 433 (2005) 834-841.

[82] C.C. Huang, M. Tang, M.Y. Zhang, S. Majeed, E. Montabana, R.L. Stanfield, D.S. Dimitrov, B. Korber, J. Sodroski, I.A. Wilson, R. Wyatt, P.D. Kwong, Structure of a V3-containing HIV-1 gp120 core, Science 310 (2005) 1025-1028.

[83] A. Trkola, T. Dragic, J. Arthos, J.M. Binley, W.C. Olson, G.P. Allaway, C. ChengMayer, J. Robinson, P.J. Maddon, J.P. Moore, CD4-dependent, antibodysensitive interactions between HIV-1 and its co-receptor CCR-5, Nature 384 (1996) 184-187.

[84] L. Wu, N.P. Gerard, R. Wyatt, H. Choe, C. Parolin, N. Ruffing, A. Borsetti, A.A. Cardoso, E. Desjardin, W. Newman, C. Gerard, J. Sodroski, CD4-induced interaction of primary HIV-1 gp120 glycoproteins with the chemokine receptor CCR-5, Nature 384 (1996) 179-183.

[85] R. Wyatt, J. Sodroski, The HIV-1 envelope glycoproteins: fusogens, antigens, and immunogens, Science 280 (1998) 1884-1888.

[86] N. Madani, A.L. Perdigoto, K. Srinivasan, J.M. Cox, J.J. Chruma, J. LaLonde, M. Head, A.B. Smith 3rd, J.G. Sodroski, Localized changes in the gp120 envelope glycoprotein confer resistance to human immunodeficiency virus entry inhibitors BMS-806 and \#155, J. Virol. 78 (2004) 3742-3752.

[87] D.C. Chan, D. Fass, J.M. Berger, P.S. Kim, Core structure of gp41 from the HIV envelope glycoprotein, Cell 89 (1997) 263-273.

[88] S.Jiang, A.K. Debnath, Development of HIV entry inhibitors targeted to the coiledcoil regions of gp41, Biochem. Biophys. Res. Commun. 269 (2000) 641-646.

[89] D.C. Chan, C.T. Chutkowski, P.S. Kim, Evidence that a prominent cavity in the coiled coil of HIV type 1 gp41 is an attractive drug target, Proc. Natl. Acad. Sci. U.S.A. 95 (1998) 15613-15617.

[90] R.A. Furuta, C.T. Wild, Y. Weng, C.D. Weiss, Capture of an early fusion-active conformation of HIV-1 gp41, Nat. Struct. Biol. 5 (1998) 276-279.

[91] N.R. Kilgore, K. Salzwedel, M. Reddick, G.P. Allaway, C.T. Wild, Direct evidence that C-peptide inhibitors of human immunodeficiency virus type 1 entry bind to the gp $41 \mathrm{~N}$-helical domain in receptor-activated viral envelope, J. Virol. 77 (2003) 7669-7672.

[92] Y. Kliger, Y. Shai, Inhibition of HIV-1 entry before gp41 folds into its fusionactive conformation, J. Mol. Biol. 295 (2000) 163-168

[93] S.E. Schneider, B.L. Bray, C.J. Mader, P.E. Friedrich, M.W. Anderson, T.S. Taylor, N. Boshernitzan, T.E. Niemi, B.C. Fulcher, S.R. Whight, J.M. White, R.J. Greene, L.E. Stoltenberg, M. Lichty, Development of HIV fusion inhibitors, J. Pept. Sci. 11 (2005) 744-753.

[94] H. Ji, C. Bracken, M. Lu, Buried polar interactions and conformational stability in the simian immunodeficiency virus (SIV) gp41 core, Biochemistry 39 (2000) 676-685.

[95] M. Eilers, U. Roy, D. Mondal, MRP (ABCC) transporters-mediated efflux of anti-HIV drugs, saquinavir and zidovudine, from human endothelial cells, Exp. Biol. Med. (Maywood) 233 (2008) 1149-1160.

[96] R.A. Fisher, J.M. Bertonis, W. Meier, V.A. Johnson, D.S. Costopoulos, T. Liu, R. Tizard, B.D. Walker, M.S. Hirsch, R.T. Schooley, et al., HIV infection is blocked in vitro by recombinant soluble CD4, Nature 331 (1988) 76-78.

[97] E.S. Daar, X.L. Li, T. Moudgil, D.D. Ho, High concentrations of recombinant soluble CD4 are required to neutralize primary human immunodeficiency virus type 1 isolates, Proc. Natl. Acad. Sci. U.S.A. 87 (1990) 6574-6578.

[98] J.M. Jacobson, R.J. Israel, I. Lowy, N.A. Ostrow, L.S. Vassilatos, M. Barish, D.N. Tran, B.M. Sullivan, T.J. Ketas, T.J. O'Neill, K.A. Nagashima, W. Huang C.J. Petropoulos, J.P. Moore, P.J. Maddon, W.C. Olson, Treatment of advanced human immunodeficiency virus type 1 disease with the viral entry inhibitor PRO 542, Antimicrob. Agents Chemother. 48 (2004) 423-429.

[99] E. De Clercq, Recent highlights in the development of new antiviral drugs, Curr. Opin. Microbiol. 8 (2005) 552-560.

[100] A. Stone, Microbicides: a new approach to preventing HIV and other sexually transmitted infections, Nat. Rev. Drug Discov. 1 (2002) 977-985.

[101] Global Advocacy for HIV Prevention-AVAC. http://www.avac.org/ht/d/sp/i/ 3513/pid/3513 (2011) (accessed January).

[102] B.J. Dezube, T.A. Dahl, T.K. Wong, B. Chapman, M. Ono, N. Yamaguchi, S.D. Gillies, L.B. Chen, C.S. Crumpacker, A fusion inhibitor (FP-21399) for the treatment of human immunodeficiency virus infection: a phase I study, J. Infect. Dis. 182 (2000) 607-610.

[103] P.F. Lin, W. Blair, T. Wang, T. Spicer, Q. Guo, N. Zhou, Y.F. Gong, H.G. Wang, R. Rose, G. Yamanaka, B. Robinson, C.B. Li, R. Fridell, C. Deminie, G. Demers, Z. Yang, L. Zadjura, N. Meanwell, R. Colonno, A small molecule HIV-1 inhibitor that targets the HIV-1 envelope and inhibits CD4 receptor binding, Proc. Natl. Acad. Sci. U.S.A. 100 (2003) 11013-11018.

[104] Z. Si, N. Madani, J.M. Cox, J.J. Chruma, J.C. Klein, A. Schon, N. Phan, L. Wang, A.C. Biorn, S. Cocklin, I. Chaiken, E. Freire, A.B. Smith 3rd, J.G. Sodroski, Smallmolecule inhibitors of HIV-1 entry block receptor-induced conformational changes in the viral envelope glycoproteins, Proc. Natl. Acad. Sci. U.S.A. 101 (2004) 5036-5041.

[105] H.T. Ho, L. Fan, B. Nowicka-Sans, B. McAuliffe, C.B. Li, G. Yamanaka, N. Zhou, H. Fang, I. Dicker, R. Dalterio, Y.F. Gong, T. Wang, Z. Yin, Y. Ueda, J. Matiskella, J. Kadow, P. Clapham, J. Robinson, R. Colonno, P.F. Lin, Envelope conformational changes induced by human immunodeficiency virus type 1 attachment inhibitors prevent CD4 binding and downstream entry events, J. Virol. 80 (2006) 4017-4025.

[106] Attachment inhibitor may hold promise for future. BMS-488043 demonstrates safety, AIDS Alert 19 (2004) 57-58.

[107] S. Jiang, K. Lin, N. Strick, A.R. Neurath, HIV-1 inhibition by a peptide, Nature 365 (1993) 113.

[108] C.T. Wild, D.C. Shugars, T.K. Greenwell, C.B. McDanal, T.J. Matthews, Peptides corresponding to a predictive alpha-helical domain of human immunodeficiency virus type 1 gp41 are potent inhibitors of virus infection, Proc. Natl. Acad. Sci. U.S.A. 91 (1994) 9770-9774.

[109] J.P. Lalezari, K. Henry, M. O'Hearn, J.S. Montaner, P.J. Piliero, B. Trottier, S. Walmsley, C. Cohen, D.R. Kuritzkes, J.J. Eron Jr., J. Chung, R. DeMasi, L. Donatacci, C. Drobnes, J. Delehanty, M. Salgo, Enfuvirtide, an HIV-1 fusion inhibitor, for drug-resistant HIV infection in North and South America, N. Engl. J. Med. 348 (2003) 2175-2185.

[110] A.S. Fauci, HIV and AIDS: 20 years of science, Nat. Med. 9 (2003) 839-843.

[111] R.M. Gulick, New antiretroviral drugs, Clin. Microbiol. Infect. 9 (2003) 186-193.

[112] C. Wild, T. Oas, C. McDanal, D. Bolognesi, T. Matthews, A synthetic peptide inhibitor of human immunodeficiency virus replication: correlation between solution structure and viral inhibition, Proc. Natl. Acad. Sci. U.S.A. 89 (1992) 10537-10541.

[113] C.A. Bewley, J.M. Louis, R. Ghirlando, G.M. Clore, Design of a novel peptide inhibitor of HIV fusion that disrupts the internal trimeric coiled-coil of gp41, J. Biol. Chem. 277 (2002) 14238-14245.

[114] D.M. Eckert, V.N. Malashkevich, L.H. Hong, P.A. Carr, P.S. Kim, Inhibiting HIV1 entry: discovery of D-peptide inhibitors that target the gp41 coiled-coil pocket, Cell 99 (1999) 103-115.

[115] S. Jiang, H. Lu, S. Liu, Q. Zhao, Y. He, A.K. Debnath, N-substituted pyrrole derivatives as novel human immunodeficiency virus type 1 entry inhibitors that interfere with the gp41 six-helix bundle formation and block virus fusion, Antimicrob. Agents Chemother. 48 (2004) 4349-4359.

[116] G. Zhou, D. Wu, E. Hermel, E. Balogh, M. Gochin, Design, synthesis, and evaluation of indole compounds as novel inhibitors targeting Gp41, Bioorg. Med. Chem. Lett. 20 (2010) 1500-1503.

[117] T. Fujioka, Y. Kashiwada, R.E. Kilkuskie, L.M. Cosentino, L.M. Ballas, J.B. Jiang, W.P. Janzen, I.S. Chen, K.H. Lee, Anti-AIDS agents, 11. Betulinic acid and platanic acid as anti-HIV principles from Syzigium claviflorum, and the anti-HIV activity of structurally related triterpenoids, J. Nat. Prod. 57 (1994) 243-247.

[118] F. Soler, C. Poujade, M. Evers, J.C. Carry, Y. Henin, A. Bousseau, T. Huet, R. Pauwels, E. De Clercq, J.F. Mayaux, J.B. Le Pecq, N. Dereu, Betulinic acid derivatives: a new class of specific inhibitors of human immunodeficiency virus type 1 entry, J. Med. Chem. 39 (1996) 1069-1083.

[119] M. Evers, C. Poujade, F. Soler, Y. Ribeill, C. James, Y. Lelievre, J.C. Gueguen, D. Reisdorf, I. Morize, R. Pauwels, E. De Clercq, Y. Henin, A. Bousseau, J.F. Mayaux, J.B. Le Pecq, N. Dereu, Betulinic acid derivatives: a new class of human immunodeficiency virus type 1 specific inhibitors with a new mode of action, J. Med. Chem. 39 (1996) 1056-1068.

[120] R.H. Cichewicz, S.A. Kouzi, Chemistry, biological activity, and chemotherapeutic potential of betulinic acid for the prevention and treatment of cancer and HIV infection, Med. Res. Rev. 24 (2004) 90-114.

[121] A.K. Debnath, L. Radigan, S. Jiang, Structure-based identification of small molecule antiviral compounds targeted to the gp41 core structure of the human immunodeficiency virus type 1, J. Med. Chem. 42 (1999) 3203-3209.

[122] M. Ferrer, T.M. Kapoor, T. Strassmaier, W. Weissenhorn, J.J. Skehel, D. Oprian, S.L. Schreiber, D.C. Wiley, S.C. Harrison, Selection of gp41-mediated HIV-1 cell entry inhibitors from biased combinatorial libraries of non-natural binding elements, Nat. Struct. Biol. 6 (1999) 953-960. 
[123] S.H. Xiang, P.D. Kwong, R. Gupta, C.D. Rizzuto, D.J. Casper, R. Wyatt, L. Wang, W.A. Hendrickson, M.L. Doyle, J. Sodroski, Mutagenic stabilization and/or disruption of a CD4-bound state reveals distinct conformations of the human immunodeficiency virus type 1 gp120 envelope glycoprotein, J. Virol. 76 (2002) 9888-9899.

[124] W. Weissenhorn, A. Dessen, S.C. Harrison, J.J. Skehel, D.C. Wiley, Atomic structure of the ectodomain from HIV-1 gp41, Nature 387 (1997) 426-430.

[125] S.Q. Liu, C.Q. Liu, Y.X. Fu, Molecular motions in HIV-1 gp120 mutants reveal their preferences for different conformations, J. Mol. Graph Model. 26 (2007) 306-318.

[126] F. Manetti, C. Tintori, M. Armand-Ugon, I. Clotet-Codina, S. Massa, R. Ragno, J.A. Este, M. Botta, A combination of molecular dynamics and docking calculations to explore the binding mode of ADS-J1, a polyanionic compound endowed with anti-HIV-1 activity, J. Chem. Inf. Model. 46 (2006) 1344-1351.

[127] J.L. Gabriel, W.M. Mitchell, Proposed atomic structure of a truncated human immunodeficiency virus glycoprotein gp120 derived by molecular modeling: target CD4 recognition and docking mechanism, Proc. Natl. Acad. Sci. U.S.A. 90 (1993) 4186-4190.

[128] S.T. Hsu, A.M. Bonvin, Atomic insight into the CD4 binding-induced conformational changes in HIV-1 gp120, Proteins 55 (2004) 582-593.

[129] Y. Pan, B. Ma, O. Keskin, R. Nussinov, Characterization of the conformational state and flexibility of HIV-1 glycoprotein gp120 core domain, J. Biol. Chem. 279 (2004) 30523-30530.

[130] Y. Pan, B. Ma, R. Nussinov, CD4 binding partially locks the bridging sheet in gp120 but leaves the beta2/3 strands flexible, J. Mol. Biol. 350 (2005) 514-527.

[131] R. Kong, J.J. Tan, X.H. Ma, W.Z. Chen, C.X. Wang, Prediction of the binding mode between BMS-378806 and HIV-1 gp120 by docking and molecular dynamics simulation, Biochim. Biophys. Acta 1764 (2006) 766-772.
[132] M. Caffrey, Model for the structure of the HIV gp41 ectodomain: insight into the intermolecular interactions of the gp41 loop, Biochim. Biophys. Acta 1536 (2001) 116-122.

[133] M. Caffrey, M. Cai, J. Kaufman, S.J. Stahl, P.T. Wingfield, D.G. Covell, A.M. Gronenborn, G.M. Clore, Three-dimensional solution structure of the 44 kDa ectodomain of SIV gp41, EMBO J. 17 (1998) 4572-4584.

[134] S. Kamath, T.C. Wong, Membrane structure of the human immunodeficiency virus gp41 fusion domain by molecular dynamics simulation, Biophys. J. 83 (2002) 135-143.

[135] J.H. Kim, T.L. Hartley, A.R. Curran, D.M. Engelman, Molecular dynamics studies of the transmembrane domain of Gp41 from HIV-1, Biochim. Biophys. Acta (2009).

[136] A.M. Martins do Canto, A.J. Palace Carvalho, J.P. Prates Ramalho, L.M. Loura T-20 and T-1249 HIV fusion inhibitors' structure and conformation in solution: a molecular dynamics study, J. Pept. Sci. 14 (2008) 442-447.

[137] B. Strockbine, R.C. Rizzo, Binding of antifusion peptides with HIVgp41 from molecular dynamics simulations: quantitative correlation with experiment Proteins 67 (2007) 630-642.

[138] S. Liu, S. Jiang, Z. Wu, L. Lv, J. Zhang, Z. Zhu, S. Wu, Identification of inhibitors of the HIV-1 gp41 six-helix bundle formation from extracts of Chinese medicinal herbs Prunella vulgaris and Rhizoma cibotte, Life Sci. 71 (2002) 1779-1791.

[139] S. Liu, H. Lu, Q. Zhao, Y. He, J. Niu, A.K. Debnath, S. Wu, S. Jiang, Theaflavin derivatives in black tea and catechin derivatives in green tea inhibit HIV-1 entry by targeting gp41, Biochim. Biophys. Acta 1723 (2005) 270-281.

[140] S. Lee-Huang, P.L. Huang, D. Zhang, J.W. Lee, J. Bao, Y. Sun, Y.T. Chang J. Zhang, Discovery of small-molecule HIV-1 fusion and integrase inhibitors oleuropein and hydroxytyrosol: part I. fusion [corrected] inhibition, Biochem. Biophys. Res. Commun. 354 (2007) 872-878.

[141] J. Bao, D.W. Zhang, J.Z. Zhang, P.L. Huang, S. Lee-Huang, Computational study of bindings of olive leaf extract (OLE) to HIV-1 fusion protein gp41, FEBS Lett. 581 (2007) 2737-2742. 